\title{
AFIRMAÇÃO E PROMOÇÃO DO DIREITO ÀS DIFERENÇAS DAS PESSOAS COM DEFICIÊNCIA E AS CONTRIBUIÇÕES DO SISTEMA INTERAMERICANO DE DIREITOS HUMANOS
}

\author{
AFFIRMATION AND PROMOTION OF THE DIFFERENCES OF PERSONS WITH \\ DESABILITIES AND CONTRIBUTIONS OF THE INTER-AMERICAN SYSTEM OF \\ HUMAN RIGHTS
}

\section{AFIRMACIÓN Y PROMOCIÓN DEL DERECHO A LAS DIFERENCIAS DE LAS PERSONAS CON DISCAPACIDAD Y LAS CONTRIBUCIONES DEL SISTEMA INTERAMERICANO DE DERECHOS HUMANOS}

\author{
Pedro Pulzatto Peruzzo \\ https://orcid.org/0000-0001-5270-8674 / http://lattes.cnpq.br/5126921195345108 / peruzzopp@hotmail.com \\ Pontifícia Universidade Católica de Campinas - PUC Campinas. \\ Campinas, SP, Brasil.
}

LUCAS SILVA LOPES

https://orcid.org/0000-0003-3677-7922 / http://lattes.cnpq.br/5501191622689403 / llucassilvalopes@gmail.com Pontifícia Universidade Católica de Campinas - PUC Campinas.

Campinas, SP, Brasil.

\begin{abstract}
RESUMO
O presente artigo tem por objetivo a análise do direito às diferenças das pessoas com deficiência no Sistema Interamericano de Direitos Humanos, partindo da hipótese de que a observância das orientações emanadas desse sistema regional tem o condão de fornecer à jurisdição e às políticas públicas internas uma concepção mais completa a respeito desse grupo de indivíduos. As pessoas com deficiência são aquelas que apresentam diferentes formas de estar no mundo e que demandam a garantia de recursos materiais e comportamentais para o exercício de seus direitos. A linha de trabalho adotada neste artigo parte da compreensão e descrição das diferentes concepções acerca da deficiência, prosseguindo com a análise do direito às diferenças considerando documentos internacionais e a jurisprudência da Corte Interamericana de Direitos Humanos. Destaca-se o potencial inclusivo da incorporação, pelo direito interno, das diretrizes hermenêuticas construídas no plano internacional sobre os direitos da pessoa com deficiência como compromisso com a cooperação internacional, colaborando com a ressignificação sobre a experiência da deficiência de forma alinhada com as agendas globais e regionais.
\end{abstract}

Palavras-chave: Pessoas com deficiência; Direito às diferenças; Sistema Interamericano de Direitos Humanos; Cooperação internacional.

\begin{abstract}
The purpose of this article is to analyze the right to the differences of persons with disabilities in the Inter - American System of Human Rights, based on the hypothesis that compliance with the guidelines emanating from this regional system has the purpose of providing to the jurisdiction and the internal public policies a more complete conception about this group of individuals. People with disabilities are those who present different ways of being in the world and who demand the guarantee of material and behavioral resources for the exercise of their rights. The line of work adopted in this article is based on the understanding and description of the different conceptions about disability, proceeding with the analysis of the right to differences considering international documents and the jurisprudence of the Inter-American Court of Human Rights. It highlights the inclusive potential of incorporating under domestic law the hermeneutical guidelines built in the international law about the rights of persons with disabilities in a
\end{abstract}


commitment to international cooperation, collaborating with the resignification about the experience of disability in line with global and regional agendas.

Keywords: People with disabilities; Right to differences; Inter-American System of Human Rights; International cooperation.

\section{RESUMEN}

El propósito de este artículo es analizar el derecho a las diferencias de las personas con discapacidad en el sistema interamericano de derechos humanos, sobre la base de la hipótesis de que el cumplimiento de las directrices que emanan de este sistema regional tiene el poder de proporcionar a la jurisdicción y las políticas públicas internas una noción más completa respecto de este grupo de personas. Las personas con discapacidad son aquellas que presentan diferentes formas de estar en el mundo y que exigen la garantía de recursos materiales y de comportamiento para el ejercicio de sus derechos. La línea de trabajo adoptada en este artículo comienza con una comprensión y descripción de las diferentes concepciones sobre discapacidad, siguiendo con el análisis del derecho a las diferencias teniendo en cuenta los documentos internacionales y la jurisprudencia de la Corte Interamericana de Derechos Humanos. Destaca el potencial inclusivo de la incorporación de pautas hermenéuticas por el derecho interno de los retos construidos a nivel internacional sobre los derechos de las personas con discapacidad y como un compromiso con la cooperación internacional, colaborando con la redefinición de la experiencia de la discapacidad en linea con las agendas globales y regionales.

Palabras clave: personas con discapacidad; Derecho a las diferencias; Sistema interamericano de derechos humanos; Cooperación internacional

\section{SUMÁRIO}

INTRODUÇÃO; 1 CONCEPÇÕES ACERCA DA DEFICIÊNCIA E O MODELO SOCIAL; 2 AS DIFERENÇAS COMO DIREITO HUMANO; 3 A AFIRMAÇÃO DO MODELO SOCIAL DA DEFICIÊNCIA PELA CORTE INTERAMERICANA DE DIREITOS HUMANOS; CONCLUSÃO; REFERÊNCIAS.

\section{INTRODUÇÃO}

Ao mesmo tempo em que as minorias têm se afirmado a partir de pautas específicas e a afirmação histórica dos direitos humanos tem contribuído muito para isso, ${ }^{1}$ são as diferenças, enquanto direito fundamental, que constituem o principal ponto de contato entre as lutas de

\footnotetext{
${ }^{1} \mathrm{O}$ fato de as minorias socioculturais se valerem da categoria "direitos humanos" como meio de luta por seus direitos, impossibilita uma leitura simplista, que tenda a ver os direitos humanos apenas como mais um instrumento de dominação e opressão do Ocidente sobre grupos subordinados. Embora, em muitos casos, valores ligados à afirmação dos direitos humanos - individualismo, democracia, universalismo -, e mesmo, a categoria "direitos humanos", sejam vistos como mais uma forma de imperialismo do Ocidente para com o "resto" do mundo, existem minorias tanto no Ocidente quanto em países não-ocidentais que utilizam a categoria "direitos humanos" como forma de proteção e luta por direitos. Rodolfo Stavenhagen tem indicado o recurso freqüente dos povos indígenas aos direitos humanos como forma de proteção, especialmente quando as violações são praticadas por parte dos Estados. Alcida Ramos tem demonstrado que os direitos humanos, como uma "faca de dois gumes", vêm freqüentemente sendo utilizados mais a favor dos povos indígenas - principalmente a partir da sua associação com as ONGs voltadas para a causa indígena -, do que como instrumento de dominação do mundo ocidental sobre minorias socioculturais (...). SOUSA, Rosinaldo S. Direitos Humanos através da História recente em uma Perspectiva Antropológica.In Roberto Kant de Lima; Regina Novais. (Org.). Antropologia e Direitos Humanos. Niterói: EdUFF, v. 30, 2002, p. 47-80.
} 
diferentes grupos minoritários, na medida em que é contra a diversidade que a violência é perpetrada em suas diferentes formas (violência de Estado, preconceito e discriminação entre particulares, negação de acesso ao mercado de trabalho etc.).

O presente artigo surgiu de uma pesquisa e do esforço conjunto do professor orientador (cujo projeto de pesquisa individual tem como objeto a luta de grupos minoritários no Sistema Interamericano de Direitos Humanos) e do estudante que, como pessoa com deficiência, se propôs a pensar o Direito e fazer suas lutas diárias a partir de uma leitura estrutural das causas das violências que sofrem as pessoas com deficiências e as relações dessas lutas com as lutas de outros grupos minoritários.

Nesse sentido, e aproveitando os resultados das trocas que experenciamos durante a pesquisa, faremos uma análise das contribuições do Sistema Interamericano de Direitos Humanos (SIDH) para a afirmação e promoção dos direitos das pessoas com deficiência, analisando de forma detida um ponto de contato específico que une as pautas de luta por direitos deste grupo com as pautas de tantos outros grupos social e culturalmente diferenciados. Esse ponto de contato é o fato de esses grupos serem excluídos do projeto político dos Estados nacionais ${ }^{2}$ em razão das diferenças que marcam as formas específicas de estar no mundo, formas essas que destoam do modelo hegemônico imposto por quem exerce o poder político e econômico na

2 Laclau desenvolve uma análise bastante pertinente a esse respeito tendo como foco os "novos movimentos sociais": "Within such a perspective, we can formulate the distinction between the social struggles of the 19th and 20th centuries as follows. In the 19th century, social struggles led not as much towards a proliferation of political spaces and a politicization of each social antagonism, but rather to the construction of ways of giving to these antagonisms access to a relatively unified political space. To this extent, there was always a distance between the areas of emergence of antagonisms and the area of construction of the political. As a result of that, the presence of the former in the latter had to take on the form of a relation of representation. Moments of crisis in the political system were moments in which new social antagonisms directly impinged on the traditional political spaces (1830, 1848, 1871); but, in any case, these crises were always crises of a total model of society - what we have called a unified political imaginary. In recent decades, by contrast, the multiplication of points of rupture which has accompanied the increasing bureaucratization of social life and the 'commodification' of advanced industrial societies, has led to a proliferation of antagonisms; but each of them has tended to create its own space and to politicise a specific area of social relations. Feminist, ecologist, anti-institutional struggles and those of the marginal groups do not generally assume the form of antagonisms whose politicisation should lead to the representation of each of these 'interests' in a different and preconstituted political sphere, but they lead rather to a direct politicisation of the space in which they are each constituted. This means only that the moment of totalisation, the dimension of horizon of the political imaginary, is no longer constituted as a 'total model' of society, but is restricted to certain demands and certain specific social relations. The radically democratic potential of the new social movements lies precisely in this - in their implicit demand for a radically open and indeterminate view of society, in so far as every 'global' social arrangement is only the contingent result of bargaining between a plurality of spaces and not a foundational category, which would determine the meaning and limits of each of these spaces." LACLAU, E. New social movements and the plurality of the social; In SLATER, D. (org) New social movements and the State in Latin America. Amsterdam: Centrum VoorStudieenDocumentatie Vans Latijns Amerika [CEDLA], 1985, pp. 27-42. 
contramão dos projetos democráticos e republicanos consagrados não apenas nos documentos internacionais de direitos humanos, mas também na maioria das cartas constitucionais vigentes.

Existem, no Brasil, segundo dados do último censo do IBGE (2010), 45.606.048 de brasileiros que se diferenciam socialmente em razão de alguma deficiência. Consistindo em $23,9 \%^{3}$ da população total, dado número expressivo normalmente assusta ao evidenciar o quão apagadas do convívio social estão as pessoas com deficiência. Na mesma toada de obscurecimento das minorias, dos estimados 5.000.000 de indígenas que viviam no Brasil em 1500, apenas 817.962 indivíduos se autodeclararam indígenas no censo o IBGE de 2010, sendo possível afirmar que esse número também esconde centenas de milhares de indivíduos que, por vergonha da identidade indígena ou por receio do preconceito, preferem se autodeclarar pardo ou branco nas consultas censitárias.

Este estudo será feito sem perder de vista os preconceitos que motivam as políticas que visam plasmar as diferenças humanas dentro de um conceito abstrato de homem, de sujeito de direito ou outra categoria abstrata demais para satisfazer a necessidade de garantir e promover as diferenças. Daremos foco especial às origens das violações dos direitos humanos das pessoas com deficiência e como o SIDH tem contribuído para a consolidação desses direitos.

As pessoas com deficiência constituem um grupo minoritário que historicamente foi marginalizado pelo não reconhecimento de seus modos singulares de existência, seja pela relação do corpo ou de sua cognição com o espaço, seja pela relação com o tempo. Do mesmo modo, foram vítimas de políticas de extermínio ${ }^{4}$ de cunho integracionistas ou higienistas que

\footnotetext{
${ }^{3}$ Atualmente está em debate a revisão do parâmetro de análise destes dados. Cf. SIMÕES, André et al (Org.). Panorama Nacional e Internacional na Produção de Indicadores Sociais: Grupos populacionais específicos e uso do tempo. Rio de Janeiro: IBGE, 2018. Disponível em: https://biblioteca.ibge.gov.br/visualizacao/livros/liv101562.pdf. Acesso em: 22 jul. 2019. Apesar dos debates, ao considerar pessoa com deficiência aquelas que apresentam "limitações mais graves", a discussão sucitada por essa revisão representa, para nós, uma violação ao propósito do modelo social consagrado na Convenção e na Lei Brasileira de Inclusão.

${ }^{4}$ Importante destacar que, tal como apontado por Chacon, no contexto do nazismo foi realizada a esterilização compulsória de cerca de 60 mil pessoas que, em sua maior parte, conviviam com alguma espécie de deficiência. Posteriormente, no mesmo regime, entraram em vigor os programas T4 e 4f13, autorizando a eutanásia e extermínio de pessoas com deficiência, estimando-se ao menos o assassinato de cerca de 100.000 destas entre 1939 a 1941. CHACON DE ALBUQUERQUE, Roberto. A Lei de Prevenção de Doenças Hereditárias e o programa de eutanásia durante a Segunda Guerra Mundial. CEJ - Revista Jurídica dos Centros de Estudos Judiciários, v. 12, no 40, 2008. p. 43-51. Disponível em: http://www.jf.jus.br/ojs2/index.php/revcej/article/viewArticle/961. Acesso em 23 jul. 2019.

Já na história nacional, Arbex narra o genocídio operado contra pessoas que possuíam alguma característica tida como desviante à época que poderia ensejar o diagnóstico de uma doença mental, no Hospital Colônia, em Barbacena, em Minas Gerais, estimando ao menos 60 mil mortes em razão das péssimas condições de isolamento e dos tratamentos compulsórios, estabelecendo, inclusive um esquema de tráfico de corpos. ARBEX, Daniela. Holocausto brasileiro. São Paulo: Geração Editorial, 2013. p. 25-26.
} 
ISSN 1981-3694

(DOI): $10.5902 / 1981369435067$

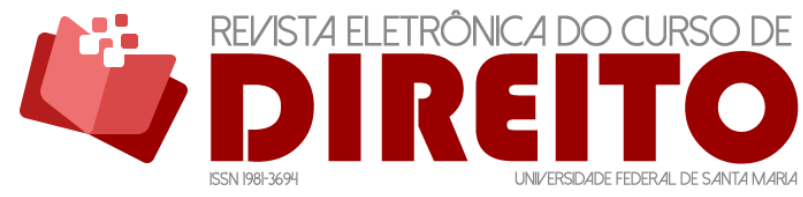

AFIRMAÇÃO E PROMOÇÃO DO DIREITO ÀS DIFERENÇAS DAS PESSOAS COM DEFICIÊNCIA E AS CONTRIBUICCÕES DO SISTEMA INTERAMERICANO DE DIREITOS HUMANOS

Pedro Pulzatto Peruzzo LUCAS SILVA LOPES

ressurgem na atualidade ante a dificuldade dos Estados nacionais e seus gestores na implementação de políticas inclusivas que, de fato, promovam o direito as diferenças.

Para esse fim, escolhemos como objeto de estudo dois julgados da Corte Interamericana de Direitos Humanos (caso Damião Ximenes Lopes vs. Brasil e caso Furlan vs. Argentina) e outros documentos internacionais que reconhecem a diferença como um direito humano e a deficiência como o resultado de barreiras sociais, e não pessoais. Buscamos entender como o processo de cooperação jurídica internacional ${ }^{5}$ no âmbito sistema interamericano de direitos humanos tem contribuído para o fortalecimento do modelo social da deficiência, da interpretação evolutiva dos direitos humanos e da reparação das desigualdades fáticas como meio de superar os limites e os preconceitos que se materializam no Direito e nas políticas públicas de Estados com pouca experiência democrática e tradição colonial, como é o caso do Brasil. Além disso, buscamos esclarecer como a consolidação dessa metodologia de proteção e promoção internacional de direitos humanos para um grupo pode ser instrumentalizada e aproveitada por outros grupos vítimas da exclusão e do preconceito.

\section{AS CONCEPÇÕES ACERCA DA DEFICIÊNCIA E O MODELO SOCIAL}

A deficiência é um conceito social e político que tradicionalmente esteve relacionado a uma série de preconceitos e a uma visão egoísta de mundo, mas que atualmente foi ressignificado como instrumento de luta e resistência para milhões de pessoas.

Para a compreensão do contexto de marginalização em que as pessoas com deficiência estão inseridas, faremos uma abordagem a respeito do "estigma", desenvolvido pelo norteamericano Erving Goffman. ${ }^{6} \mathrm{O}$ autor atribui a este termo o processo pelo qual é destacada uma

\footnotetext{
${ }^{5}$ Esse alinhamento entre o direito interno e o direito anunciado, interpretado e aplicado por organismos internacionais (em especial os de direitos humanos, como é o caso do Comitê em questão) é o que a doutrina especializada denomina cooperação jurídica vertical: "Inicialmente, distinguimos a cooperação jurídica vertical - que se dá entre organizações supranacionais e internacionais, de um lado, e Estados, de outro - e a cooperação horizontal - estabelecida entre Estados igualmente soberanos (...)." (ABADE, Denise Neves. Direitos fundamentais na cooperação jurídica internacional. - São Paulo: Saraiva, 2013, p. 40) A esse respeito, vale também referência ao que leciona André de Carvalho Ramos: "A cooperação jurídica internacional consiste no conjunto de regras internacionais e nacionais que rege atos de colaboração entre Estados, ou mesmo entre Estados e organizações internacionais, com o objetivo de facilitar o acesso à justiça." (RAMOS, André de Carvalho. O novo Direito Internacional Privado e o conflito de fontes na cooperação jurídica internacional. R. Fac. Dir. Univ. São Paulo, v. 108, p. 621 - 647 jan./dez. 2013).

${ }^{6}$ GOFFMAN, Erving. Estigma: notas sobre a manipulação da identidade deteriorada. Rio de Janeiro: LTC, 1988.
} 
ISSN 1981-3694

(DOI): $10.5902 / 1981369435067$

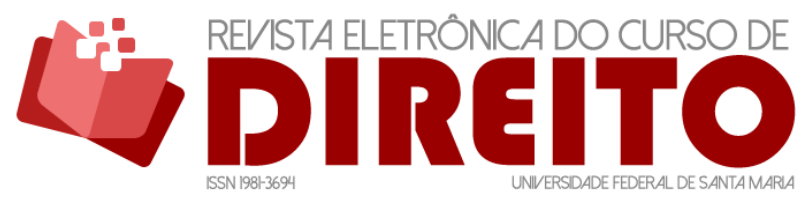

AFIRMAÇÃO E PROMOÇÃO DO DIREITO ÀS DIFERENÇAS DAS PESSOAS COM DEFICIÊNCIA E AS CONTRIBUICÕES DO SISTEMA INTERAMERICANO DE DIREITOS HUMANOS

Pedro Pulzatto Peruzzo LUCAS SILVA LOPES

característica física, cultural ou comportamental tida como sinônimo de desgraça e que é atrelada à identidade social da pessoa ou do grupo sobre o qual recai. A partir de então, são estabelecidas expectativas normativas sobre o indivíduo estigmatizado, impondo diretrizes de condutas e de vivência (ou "não vivência") que devem ser observadas como condição para a participação nos espaços previamente reservados.

0 autor registra, ainda, que o estigma se refere a uma "linguagem de relações e não de atributos"7 e tem como origem o fato de, em sociedade, categorizarmos as pessoas conforme os ambientes sociais que ocupam. Nesta lógica, a construção histórica da figura da deficiência representou a elaboração de expectativas normativas de caráter depreciativo sobre as pessoas com determinada diferença, tomando a diferença como indício de incapacidade para a realização de atividades tidas como basilares para a construção de um projeto de vida, tais como a constituição de uma família (sexualidade, direitos reprodutivos) e a ocupação de funções de destaque no âmbito laboral e acadêmico. ${ }^{8}$

A concepção da deficiência enquanto estigma faz com que a pessoa com deficiência tenha negada sua dignidade ao ser segregada do convívio social por acreditar (e fazê-las acreditar) que não são aptas à satisfação de todas as expectativas atribuídas a um ideal de normalidade:

\begin{abstract}
Enquanto o estranho está à nossa frente, podem surgir evidências de que ele tem um atributo que o torna diferente de outros que se encontram numa categoria em que pudesse ser - incluído, sendo, até, de uma espécie menos desejável num caso extremo, uma pessoa completamente má, perigosa ou fraca. Assim, deixamos de considerá-lo criatura comum e total, reduzindo-o a uma pessoa estragada e diminuída. Tal característica é um estigma, especialmente quando o seu efeito de descrédito é muito grande - algumas vezes ele também é considerado um defeito, uma fraqueza, uma desvantagem - e constitui uma discrepância específica entre a identidade social virtual e a identidade social real. ${ }^{9}$
\end{abstract}

\footnotetext{
${ }^{7}$ GOFFMAN, Erving. Estigma: notas sobre a manipulação da identidade deteriorada. Rio de Janeiro: LTC, 1988. p. 06

8 O último Censo de 2010 do IBGE apontou que a taxa de alfabetização da população brasileira em geral é de $90,6 \%$, enquanto a das pessoas com deficiência é de $81,7 \%$. Do mesmo modo, a pesquisa destacou que $61,1 \%$ das pessoas com deficiência no Brasil não possuem nenhum grau de instrução, enquanto a taxa de brasileiros sem deficiência na mesma situação é de $38,2 \%$. (BRASIL. Secretaria de Direitos Humanos da Presidência da República, Cartilha do Censo 2010: pessoas com deficiência [online]. Brasília, 2012. p. 15-18.) Disponível em: https://biblioteca.ibge.gov.br/visualizacao/periodicos/94/cd_2010_religiao_deficiencia.pdf. Acesso em 23 jul. 2019.

9 GOFFMAN, Erving. Estigma: notas sobre a manipulação da identidade deteriorada. Rio de Janeiro: LCT, 1988.
} 
ISSN 1981-3694

(DOI): $10.5902 / 1981369435067$

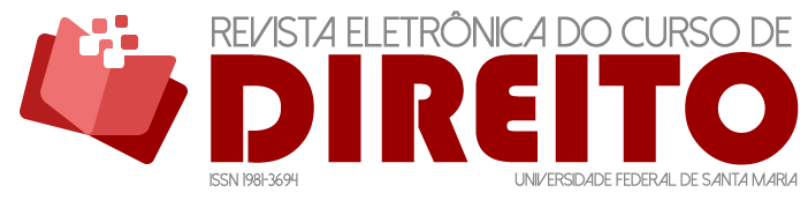

AFIRMAÇÃO E PROMOÇÃO DO DIREITO ÀS DIFERENÇAS DAS PESSOAS COM DEFICIÊNCIA E AS CONTRIBUICCÕES DO SISTEMA INTERAMERICANO DE DIREITOS HUMANOS

Pedro Pulzatto Peruzzo LUCAS SILVA LOPES

Diante disto, o movimento das pessoas com deficiência se apresenta atualmente com dois propósitos: romper a categoria depreciativa em que aqueles que os estigmatizam os inserem, incorporando-se à categoria de ser humano, no mesmo instante em que ressignifica a deficiência, fazendo com que a sociedade a reconheça como consequência das desigualdades sociais e da intolerância à diversidade e não mais enquanto um fim em si mesmo, ou seja, como justificativa à segregação ou qualquer outra conduta depreciativa.

Quanto à pessoa com deficiência, Marques (1987), ${ }^{10}$ à sua época, destacava a existência de três processos contínuos que delimitavam as diferentes concepções acerca da deficiência pautadas no lugar que essas pessoas ocupariam no mundo: (I) a exclusão, seja pela execução de recém-nascidos ou pelo abandono; (II) a segregação, pautada pelo isolamento deste grupo minoritário em instituições que carregavam o caráter assistencialista e sob a égide da caridade; (III) a integração, norteada pela ideia de normalidade, analisando a deficiência do ponto de vista puramente biológico/médico, enquanto desvio que devesse ser controlado a partir de um modelo de perfeição hegemônico.

Atualmente, temos presenciado um processo contínuo de consolidação da ideia de inclusão, por meio do modelo social da deficiência. Essa reinvindicação do movimento, Incorporada como diretriz em tratados e convenções internacionais de direitos humanos, ${ }^{11}$ busca superar os absurdos da exclusão e da segregação, bem como a insuficiência da integração.

Insta ressaltar que, embora a afirmação da deficiência como estigma tenha ocorrido em diferentes contextos históricos, Marques ${ }^{12}$ apresenta algumas exceções em que dada condição possuía caráter sacro. A exemplo, o povo Xagga, na Tanzânia, para quem pessoas com deficiência são tidas como invioláveis pelo fato de serem responsáveis por manterem selados os espíritos malignos, e o povo Semang, na Malásia, que atribui à deficiência um signo de sabedoria. Esses exemplos apenas confirmam que o estigma ou respeito à deficiência decorrem

\footnotetext{
${ }^{10}$ SILVA, Otto Marques da. A epopeia ignorada: (a pessoa deficiente na historia do mundo de ontem e de hoje). São Paulo: CEDAS,1987.

$11 \mathrm{O}$ artigo III da Convenção Interamericana para a Eliminação de Todas as Formas de Discriminação contra as Pessoas Portadoras de Deficiência, promulgada pelo decreto $\mathrm{n}^{\circ} 3.956$ de 8 de outubro de 2001, estabelece como dever do Estado a elaboração e execução de medidas de diversas naturezas com vistas à plena integração na sociedade. Posteriormente, de forma mais apropriada, a Convenção da ONU Convenção Internacional sobre os Direitos das Pessoas com Deficiência e seu Protocolo Facultativo trabalha com o conceito de "inclusão". Em seu artigo 19, assegura o direito à vida independente e inclusão na comunidade. BRASIL. Decreto $\mathrm{N}^{\circ}$ 6.949, de 25 de agosto de 2009. Promulga a Convenção Internacional sobre os Direitos das Pessoas com Deficiência e seu Protocolo Facultativo, assinados em Nova York, em 30 de março de 2007. Diário Oficial da União, Brasília, DF, 26 ago. 2009. Disponível em: http://www.planalto.gov.br/ccivil_03/_ato2007-2010/2009/decreto/d6949.htm. Acesso em: 23 jul. 2019. 12 SILVA, Otto Marques da. A epopeia ignorada: (a pessoa deficiente na historia do mundo de ontem e de hoje). São Paulo: CEDAS,1987. p. 28.
} 
ISSN 1981-3694

(DOI): $10.5902 / 1981369435067$

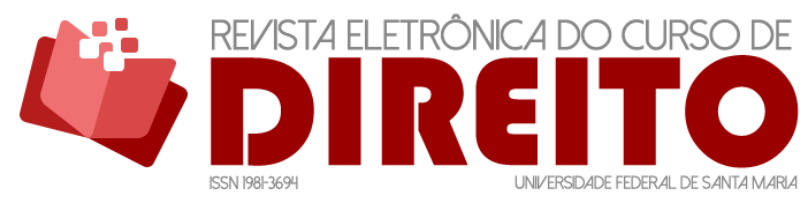

AFIRMAÇÃO E PROMOÇÃO DO DIREITO ÀS DIFERENÇAS DAS PESSOAS COM DEFICIÊNCIA E AS CONTRIBUICCÕES DO SISTEMA INTERAMERICANO DE DIREITOS HUMANOS

Pedro Pulzatto Peruzzo LUCAS SILVA LOPES

de convenções sociais e, por isso mesmo, os embaraços enfrentados pela pessoa com deficiência possuem sua raiz num preconceito nascido de escolhas sociais, e não em fatores biológicos determinantes de uma condição de sofrimento.

Entretanto, considerando as orientações do Cristianismo e dos avanços científicos e tecnológicos, apesar do reconhecimento do caráter humano da pessoa com deficiência, tal fato não resultou no reconhecimento deste grupo enquanto titular do mesmo patamar de dignidade que os demais indivíduos. Isso pode ser afirmado, pois só poderia ser permitido à pessoa com deficiência desfrutar dos mesmos espaços e oportunidades construídos para o restante da sociedade se, após o processo de reabilitação ou isolamento, fosse capaz de encaixar-se no padrão de normalidade estabelecido, imputando-se, assim, todo o esforço e culpa por eventual dificuldade à pessoa com deficiência. Destarte, insta ressaltar que dada prática discriminatória ainda se encontra presente na sociedade e, inclusive, dentro de órgãos públicos e instituições de ensino. ${ }^{13}$

A perpetuidade dessas práticas excludentes, tais como as políticas governamentais calcadas na caridade e assimilação das diferenças, possuem como origem o enraizamento da lógica da integração, conforme apontado por Werneck, ${ }^{14}$ tendo como pressuposto a ideia de que são bastantes pequenas concessões, ou seja, pequenas ajudas pontuais (esmolas) sem qualquer reforma estrutural (autonomia).

Nessa lógica, as pessoas com deficiência são tratadas como espécie homogênea e devem adaptar-se à dinâmica social já consolidada, desconsiderando as diversas formas de deficiência a exigir adequações no espaço público, bem como as subjetividades de cada indivíduo com deficiência que se expressam na convivência familiar, na participação comunitária, em movimentos sociais, orientação sexual, etc.

\footnotetext{
$13 \mathrm{O}$ advogado Dilto Marques Nunes foi impedido de exercer suas funções no fórum de São Francisco de Paula, no Rio Grande do Sul, devido à falta de acessibilidade, sendo sugerido ao seu cliente, por um dos magistrados, a troca de seu representante legal, recusando-se a realizar a mudança do local da audiência para cômodo no térreo. Cf. http://g1.globo.com/rs/rio-grande-do-sul/noticia/2015/03/semacessibilidade-juiz-sugere-troca-de-advogado-cadeirante-em-audiencia.html. Acesso em: 23 jul. 2019. No mesmo sentido, a ADI 5357 proposta pela Confederação Nacional dos Estabelecimentos de Ensino CONFENEN sobre parágrafo $1^{\circ}$ do artigo 28 e caput do artigo 30 da Lei 13.146/2015, que vedam a cobrança adicional de estudante com deficiência que necessite de qualquer espécie de adaptação. Dada ação foi apresentada sob o fundamento de que este ônus não deveria ser suportado pela iniciativa privada, mas somente pelo poder público, o que, em tese, retoma a concepção da deficiência pelo viés integracionista, haja vista a tentativa de negar a acessibilidade enquanto pauta e responsabilidade da sociedade enquanto um todo, desincumbindo a iniciativa privada de qualquer responsabilidade. Cf. http://www.stf.jus.br/portal/cms/verNoticiaDetalhe.asp?idConteudo=318570. Acesso em 23. jul. 2019 ${ }^{14}$ WERNECK, Claudia. (2003), Você é gente? Rio de Janeiro: WVA, 2003. p. 52.
} 
ISSN 1981-3694

(DOI): $10.5902 / 1981369435067$

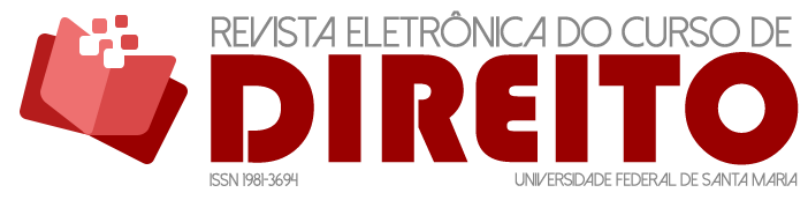

AFIRMAÇÃO E PROMOÇÃO DO DIREITO ÀS DIFERENÇAS DAS PESSOAS COM DEFICIÊNCIA E AS CONTRIBUICCÕES DO SISTEMA INTERAMERICANO DE DIREITOS HUMANOS

Pedro Pulzatto Peruzzo LUCAS SILVA LOPES

Deste modo, se a lesão que a pessoa com deficiência carrega for incompatível com o padrão de normalidade existente, ou ainda se for inviável a extinção daquele caractere tido como anormal, estaria legitimada a prática da segregação ou seria permitida sua sobrevivência em espaços pré-estipulados, confinados, minando o desenvolvimento de suas potencialidades e anulando por completo sua dignidade.

Considerando as concepções segregacionistas e integracionistas, a primeira preza pelo caráter unicamente assistencialista, concebendo a pessoa com deficiência exclusivamente como objeto de caridade e não como titular das mesmas potencialidades dos demais, enquanto a segunda descarta a possibilidade de promover mudanças na sociedade para que a pessoa com deficiência possa dela participar de maneira plena, deixando a cargo de cada pessoa o ônus de superar essas barreiras ${ }^{15}$ (o que, muitas vezes, dependerá da capacidade financeira de cada pessoa com deficiência).

Como forma de enfrentamento a essas concepções redutivistas da deficiência, na década de 70 foi criada, no Reino Unido, a Liga dos Lesados Físicos contra a Segregação, primeira organização política voltada às pessoas com deficiência. A proposta central da Liga era enfatizar a necessidade de superar a análise puramente biomédica da temática, reconhecendo, conjuntamente, sua repercussão política, social e cultural, no denominado modelo social da deficiência ${ }^{16}$ que supera a segregação e a integração com a proposta de políticas de inclusão.

O modelo social de compreensão da deficiência, construído dentro dos projetos de inclusão, propõe a revolução do conceito de deficiência ao imputar ao ambiente discriminatório e intolerante as consequências negativas da diferença que o indivíduo apresenta em seu corpo ou em seu intelecto. Em outros termos, a pessoa com alguma espécie de lesão torna-se deficiente somente quando o espaço ou as pessoas com quem convive desconsideram as peculiaridades de sua diferença ou, se reconhecem, quando atribuem a ela um caráter depreciativo.

O cerne da concepção é o reconhecimento da distinção entre "características distintivas" e "deficiência": a primeira seria o aspecto objetivo e biológico da diferenciação

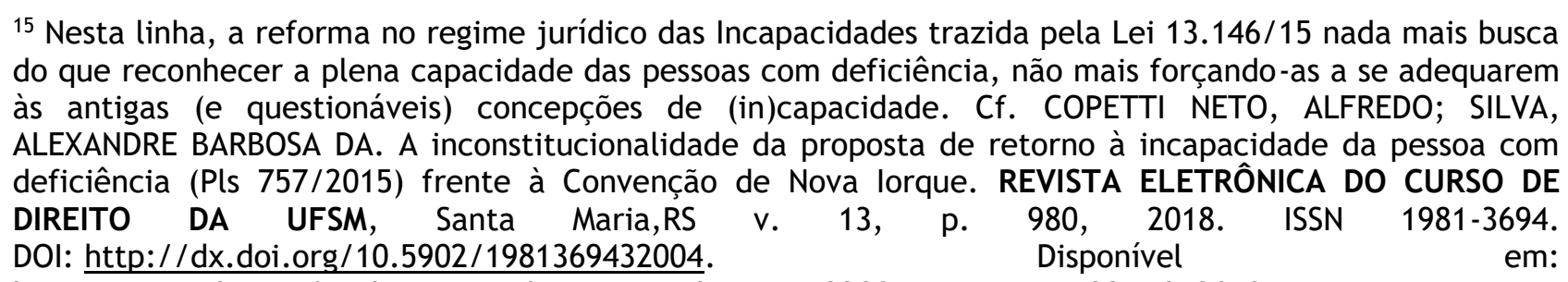
https://periodicos.ufsm.br/revistadireito/article/view/32004. Acesso em 22 Jul. 2019.

${ }_{16}$ DINIZ, Debora. 0 que é deficiência? Brasília: Brasiliense, 2007. p. 14. 
corporal e sensorial, enquanto a segunda seria resultado, não da distinção, mas de contextos sociais fechados às diferenças. Reivindica-se, assim, a urgência do tratamento da deficiência não somente do ponto de vista biomédico, mas também como pauta de justiça social. ${ }^{17}$

Essa foi a revolução dos estudos sobre deficiência surgidos no Reino Unido e nos Estados Unidos nos anos 1970. De um campo estritamente biomédico confinado aos saberes médicos, psicológicos e de reabilitação a deficiência passou a ser também um campo das humanidades. Nessa guinada acadêmica, deficiência não é mais a simples expressão de uma lesão que impõe restrições à participação social de uma pessoa. Deficiência é um conceito complexo que reconhece o corpo com lesão, mas também denuncia a estrutura social que oprime a pessoa deficiente. ${ }^{18}$

A constatação de que a deficiência é fruto de uma estrutura social discriminatória com o "modelo social" impôs ao Estado e aos particulares a responsabilidade e o dever de pensar a necessidade de reestruturação do espaço arquitetônico e do ambiente social com vistas a acolher toda e qualquer diferença, não sendo mais aceitável políticas baseadas em concessões e reformas pontuais empreendidas em espaços isolados ou, então, negando eventual responsabilidade sob o argumento de que a deficiência é consequência de mera fatalidade, não impondo dever algum a qualquer agente, seja este público ou particular. Outrossim, medidas inclusivas, tais como as de acessibilidade, apresentam caráter de direito fundamental, vez que indispensáveis para a concretização da dignidade da pessoa humana daqueles que convivem com alguma espécie de deficiência. ${ }^{19}$

Importante destacar que afirmar a urgência da substituição do viés integracionista pelo inclusivo implica reconhecer que o ambiente social discriminatório não afeta somente a pessoa com deficiência, mas sim todo ser humano que, impedido de reconhecer a pluralidade que

17 Neste sentido, o modelo social da deficiência encontra-se na Convenção Interamericana para a Eliminação de Todas as Formas de Discriminação contra as Pessoas Portadoras de Deficiência (Decreto 3.956/01), assinada na Guatemala em 07 de junho de 1999. Em seu artigo $1^{\circ}$ conceitua deficiência como: restrição física, mental ou sensorial, de natureza permanente ou transitória, que limita a capacidade de exercer uma ou mais atividades essenciais da vida diária, causada ou agravada pelo ambiente econômico e social” (grifo nosso). Igualmente, a Convenção sobre os Direitos das Pessoas com Deficiência e de seu Protocolo Facultativo, assinados em Nova lorque, em 30 de março de 2007 (Decreto 6.949/09) assevera que: "a deficiência é um conceito em evolução e que a deficiência resulta da interação entre pessoas com deficiência e as barreiras devidas às atitudes e ao ambienteque impedem a plena e efetiva participação dessas pessoas na sociedade em igualdade de oportunidades com as demais pessoas" (grifo nosso).

${ }^{18}$ DINIZ, Debora. $O$ que é deficiência? Brasília: Brasiliense, 2007. p. 09

19 PIMENTEL, MARIANA COUTO; PIMENTEL, Susana Couto. Acessibilidade como um direito fundamental: uma análise à luz das leis federais brasileiras. Revista Eletrônica do Curso de Direito da UFSM, Santa Maria, RS, v. 13, 2018, p. 93. DOI: http://dx.doi.org/10.5902/1981369427961. Disponível em: https://periodicos.ufsm.br/revistadireito/article/view/27961. Acesso em 22 Jul.2019. 
ISSN 1981-3694

(DOI): $10.5902 / 1981369435067$

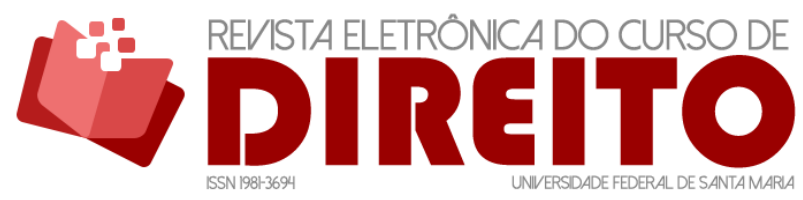

AFIRMAÇÃO E PROMOÇÃO DO DIREITO ÀS DIFERENÇAS DAS PESSOAS COM DEFICIÊNCIA E AS CONTRIBUICÕ̃ES DO SISTEMA INTERAMERICANO DE DIREITOS HUMANOS

Pedro Pulzatto Peruzzo LUCAS SILVA LOPES

marca a humanidade que lhe dignifica, torna-se meio para a reprodução das mais diversas formas de opressão. Portanto, o esforço para a criação de um ambiente inclusivo que satisfaça as necessidades e que acolha as diferenças de todos torna-se imperativo para a ordem coletiva, consolidando aquilo que Werneck ${ }^{20}$ denomina "ética da diversidade".

A extensão da pauta da inclusão de outros grupos minoritários que não pertencem à categoria das pessoas com deficiência também encontra nexo histórico como o que estamos trabalhando aqui, tendo em vista que durante toda história os estigmas pesaram não somente sobre as lesões, mas também sobre a cor da pele, a orientação sexual, o gênero, e os modos singulares de vida, a exemplo dos povos indígenas. Os estudos sobre interculturalidade e direitos humanos buscam dar conta dessa demanda histórica de grupos culturalmente diferenciados e no presente texto pretendemos contribuir exatamente com esse projeto de convivência menos violenta entre diferentes num mesmo espaço geográfico e político objetivando a participação social das minorias no espaço público de maneira equitativa:

Sem a experiência da alteridade, que nos permite compreender as nossas diferenças a partir das diferenças dos outros, os instrumentos e foros de participação social podem acabar figurando como meras reproduções de uma lógica excludente já presente na estrutura social brasileira. ${ }^{21}$

Basta lembrar a construção histórica e política do racismo cientifico, vulgo determinismo biológico, visando justificar a inferioridade do povo negro, momento em que "o homem branco constitui a norma, sendo as demais raças apenas desvios dela".22 Com base nessas "teorias" elaboravam-se diversas orientações normativas baseadas em suposta incapacidade para execução de atividades intelectuais que, no limite, desaguaram na escravidão.

Na mesma linha da estigmatização, a OMS só operou a retirada da homoafetividade da lista internacional de doenças em 1990. Digno de nota a narrativa de Arbex a respeito da internação manicomial de qualquer categoria de pessoas que apresentassem caracteres considerados como desviantes do padrão de normalidade:

20 WERNECK, Claudia. (2003), Você é gente? Rio de Janeiro: WVA, 2003. p. 29.

21 BARALDI, C. B. F. PERUZZO, P. P. Democracia e Direitos Humanos: a participação social das minorias. Santa Maria, Revista Eletrônica do Curso de Direito da UFSM, 2015. p. 360. Disponível em: https://periodicos.ufsm.br/revistadireito/article/view/19769/pdf. Acesso em: 23 jul. 2019.

22 GOULD, Stepen Jay. A falsa medida do homem. São Paulo: Martins Fontes, 1999. p. 26. 
Cerca de 70\% não tinham diagnóstico de doença mental. Eram epiléticos, alcoolistas, homossexuais, prostitutas, gente que se rebelava, gente que se tornara incômoda para alguém com mais poder. Eram meninas grávidas, violentadas por seus patrões, eram esposas confinadas para que o marido pudesse morar com a amante, eram filhas de fazendeiros as quais perderam a virgindade antes do casamento. Eram homens e mulheres que haviam extraviado seus documentos. ${ }^{23}$

A abordagem inclusiva impõe o dever de respeito às necessidades de cada indivíduo para que suas singularidades não sejam recebidas como fator pejorativo ou impeditivo de sua plena realização pessoal. Como exemplo de dado imperativo, o artigo $6^{\circ}$ da Convenção sobre os Direitos da Pessoa com Deficiência da ONU, reconhece a vulnerabilidade da mulher com deficiência, impondo a necessidade do estabelecimento de ações específicas objetivando a efetivação de seus direitos e garantias, haja vista que são frequentes vítimas de abusos sexuais e sofrem com maior intensidade o desestimulo para a ocupação de espaços laborais e acadêmicos, em decorrência não apenas dos estigmas atribuídos à sua deficiência, mas também à figura feminina.

O modelo social aponta para a possibilidade de atingir a "igualdade pela interdependência", ${ }^{24}$ ou seja, parte do pressuposto de que a necessidade de cooperação e de suporte é presente na vida de qualquer pessoa, independentemente da existência ou não da deficiência em sua vida. Nesse sentido, torna-se injustificável a discriminação de qualquer pessoa que necessite de suporte técnico ou humano para realização de atividades manuais ou manifestação de vontade. ${ }^{25}$

O reconhecimento da existência de deficiências no mundo circundante mostra-se, portanto, imprescindível. Trata-se de um movimento expansivo, de retirar o foco da pessoa e direcioná-lo para o mundo. Sem essa nova perspectiva, a deficiência permanecerá apenas sobre os ombros das pessoas com deficiência, do mesmo modo que as diferenças culturais ficarão apenas sobre os ombros dos povos tradicionais, o feminino sobre os ombros das mulheres, a liberdade de orientação sexual sobre os ombros da comunidade LGBTI e assim por diante.

\footnotetext{
${ }^{23}$ ARBEX, Daniela. Holocausto brasileiro. São Paulo: Geração Editorial, 2013. p. 25-26.

${ }^{24}$ DINIZ, Debora. O que é deficiência? Brasília: Brasiliense, 2007. p. 63.

${ }^{25}$ Nessa linha, vale a menção ao instituto da tomada de decisão apoiada recém inserido no Código Civil pátrio pela lei 13.146/2015, a Lei Brasileira de Inclusão da Pessoas com Deficiência: "Art. 1.783-A. A tomada de decisão apoiada é o processo pelo qual a pessoa com deficiência elege pelo menos 2 (duas) pessoas idoneas, com as quais mantenha vínculos e que gozem de sua confiança, para prestar-lhe apoio na tomada de decisão sobre atos da vida civil, fornecendo-lhes os elementos e informações necessários para que possa exercer sua capacidade." BRASIL. Lei ${ }^{\circ} 13.146$, de 6 de julho de 2015. Institui a Lei Brasileira de Inclusão da Pessoa com Deficiência (Estatuto da Pessoa com Deficiência). Diário Oficial da União, Brasília, 7 jul. 2015.
} 
Deficiência, cultura, gênero, orientação sexual e outras diferenças não devem ser fardos a pesarem sobre ninguém, mas motivos para o exercício da cidadania e da autonomia.

Importante registrar também que a inclusão deve preocupar-se não somente com a eliminação das barreiras físicas, mas também com as de natureza atitudinais26, tal como o racismo enfrentado pelo povo negro, os ataques aos povos indígenas por jagunços a mando de fazendeiros, o machismo que mata as mulheres, a homofobia quem mata membros da comunidade LGBTI e, por fim, ao capacitismo ${ }^{27}$ que anula a dignidade das pessoas com deficiência.

\section{AS DIFERENÇAS COMO DIREITO HUMANO}

Diante do que expusemos até aqui, inevitável considerar as diferenças como um direito humano e, tecnicamente, isso também pode ser afirmado como uma decorrência do próprio ordenamento jurídico brasileiro. 0 art. $3^{\circ}$, inciso IV, da Constituição de 1988 enuncia, dentre um dos objetivos de nossa República, a promoção do "bem de todos, sem preconceitos de origem, raça, sexo, cor, idade e quaisquer outras formas de discriminação". Do mesmo modo, o art. 5, parágrafo $2^{\circ}$, enuncia que os direitos expressos na Constituição não excluem outros direitos decorrentes do regime democrático ou de tratados internacionais em que o Brasil seja parte. ${ }^{28}$

Nessa linha, muitos documentos internacionais e nacionais de relevo afirmam o direito à diferença expressamente ou na exata medida em que imputam aos Estados a responsabilidade pela implementação de políticas para a erradicação da discriminação baseada nas diferenças.

\footnotetext{
${ }^{26}$ Nesse sentido, o artigo $3^{\circ}$, inciso IV, alínea "e", da LBI, define barreiras atitudinais como: atitudes ou comportamentos que impeçam ou prejudiquem a participação social da pessoa com deficiência em igualdade de condições e oportunidades com as demais pessoas. BRASIL. Lei $n^{\circ} 13.146$, de 6 de julho de 2015. Institui a Lei Brasileira de Inclusão da Pessoa com Deficiência (Estatuto da Pessoa com Deficiência). Diário Oficial da União, Brasília, 7 jul. 2015.

${ }^{27}$ Mello (2006:3266 - 3267) descreve o capacitismo como “(...) atitudes preconceituosas que hierarquizam sujeitos em função da adequação de seus corpos a um ideal de beleza e capacidade funcional, no mesmo instante em que destaca o desconhecimento acerca do termo e de sua inexistência em diplomas legais ou de qualquer outra categoria linguística que expresse a discriminação calcada na deficiência - em analogia ao racismo, por exemplo - ,reflexo da invisibilidade da pessoa com deficiência. MELLO, Anahi Guedes de. Deficiência, incapacidade e vulnerabilidade: do capacitismo ou a preeminência capacitista e biomédica do Comitê de Ética em Pesquisa da UFSC. Ciência\&Saúde Coletiva [online]. v. 21, n. 10. 2016. p. 3265-3276. Disponível em: http://www.scielo.br/pdf/csc/v21n10/1413-8123-csc-21-10-3265.pdf. Acesso em: 23 jul. 2019.

${ }^{28}$ BRASIL. Constituição Federal. Diário Oficial da República Federativa do Brasil, Brasília, 5 out. 1988. Disponível em: http://www.planalto.gov.br/ccivil_03/constituicao/constituicaocompilado.htm. Acesso em: 23 jul. 2019.
} 
No âmbito global, a Convenção Internacional sobre a Eliminação de Todas as Formas de Discriminação Racial de $1968^{29}$ imputa aos Estados-partes, em seu artigo II, a obrigação de adotar "meios apropriados e sem tardar uma política de eliminação da discriminação racial em todas as suas formas”. A Convenção Sobre a Eliminação de todas as Formas De Discriminação Contra a Mulher de $1979,{ }^{30}$ no artigo $2^{\circ}$, prevê a imprescindibilidade da adoção de "uma política destinada a eliminar a discriminação contra a mulher”. A Convenção 169 da Organização Internacional do Trabalho sobre Povos Indígenas e Tribais de 1989, ${ }^{31}$ estabelece como um de seus objetivos a eliminação da política assimilacionista, garantindo a igualdade de direitos e o respeito à identidade social e cultural dos povos indígenas (artigo $2^{\circ}$, item 1 , alínea b). A Convenção sobre a Proteção e Promoção da Diversidade das Expressões Culturais de $2005^{32}$ propõe medidas que visam assegurar o respeito às culturas e suas múltiplas expressões, garantindo espaço discursivo para sociedade civil no desenvolvimento deste projeto (artigo 11).

No âmbito interamericano, a Convenção Americana de Direitos Humanos ${ }^{33}$ prevê o dever de não discriminação no artigo 24. Já a Convenção Interamericana para Prevenir, Punir e Erradicar a Violência Contra a Mulher - Convenção de Belém do Pará - de $1994^{34}$ reconhece à mulher o direito a uma vida livre de violência, tanto na esfera pública como na esfera privada. $\mathrm{Na}$ mesma linha, a Convenção Interamericana Contra Toda Forma de Discriminação e

${ }^{29}$ BRASIL. Decreto $n^{\circ} 65.810$ de 08 de dezembro de 1969. Promulga a Convenção Internacional sobre a Eliminação de todas as Formas de Discriminação Racial. Diário Oficial da União, Brasília, 10 dez. 1969. Disponível em: http://www2.camara.leg.br/legin/fed/decret/1960-1969/decreto-65810-8-dezembro1969-407323-publicacaooriginal-1-pe.html. Acesso em: 23 jul. 2019.

30 BRASIL. Decreto $n^{\circ} 4.377$ de 13 de setembro de 2002. Promulga a Convenção sobre a Eliminação de Todas as Formas de Discriminação contra a Mulher, de 1979, e revoga o Decreto no 89.460, de 20 de março de 1984. Diário Oficial da União, Brasília, 16 set. 2002 . Disponível em: http://www.planalto.gov.br/ccivil_03/decreto/2002/d4377.htm. Acesso em: 24 jul. 2019.

31 BRASIL. Decreto $n^{\circ} 5.051$ de 19 de abril de 2004. Promulga a Convenção no 169 da Organização Internacional do Trabalho - OIT sobre Povos Indígenas e Tribais. Diário Oficial da União, Brasília, 20 abr. 2004. Disponível em: http://www.planalto.gov.br/ccivil_03/_ato2004-2006/2004/decreto/d5051.htm. Acesso em: 24 jul. 2019.

32 BRASIL. Decreto $n^{\circ} 6.177$ de 01 de agosto de 2007. Promulga a Convenção sobre a Proteção e Promoção da Diversidade das Expressões Culturais, assinada em Paris, em 20 de outubro de 2005. Diário Oficial da União, Brasília, 02 ago. 2007. Disponível em: http://www.planalto.gov.br/ccivil_03/_ato20072010/2007/decreto/d6177.htm. Acesso em: 24 jul. 2019.

33 BRASIL. Decreto ${ }^{\circ} 678$ de 06 de novembro de 1992. Promulga a Convenção Americana sobre Direitos Humanos (Pacto de São José da Costa Rica), de 22 de novembro de 1969. Diário Oficial da União, Brasília, 09 nov. 1992. Disponível em: http://www.planalto.gov.br/ccivil_03/Decreto/D0678.htm. Acesso em: 23 jul. 2019.

34 BRASIL. Decreto $n^{\circ} 1.973$ de 01 de agosto de 1996. Promulga a Convenção Interamericana para Prevenir, Punir e Erradicar a Violência contra a Mulher, concluída em Belém do Pará, em 9 de junho de 1994. Diário Oficial da União, Brasília, 02 out. 1996. Disponível em: http://www.planalto.gov.br/ccivil_03/decreto/1996/d1973.htm. Acesso em: 24 jul. 2019. 
Intolerância de $2013^{35}$ repudia a discriminação por motivo de orientação sexual, identidade e expressão de gênero, dentre outros caracteres.

No que diz respeito às pessoas com deficiência, a Convenção Interamericana para a Eliminação de Todas as Formas de Discriminação contra as Pessoas Portadoras de Deficiência, promulgada pelo Decreto $\mathrm{n}^{\circ} 3.956^{36}$, a Convenção Internacional sobre os Direitos da Pessoa com Deficiência de 2007 e seu Protocolo Facultativo, promulgados pelo Decreto $n^{\circ}$ 6949/09, e o Tratado de Marraqueche, promulgado pelo Decreto $n^{\circ} 9.522 / 18^{37}$ enfatizam a vedação à discriminação desencadeada pela deficiência.

No plano interno, a Lei $n^{\circ} 7.716 / 1989,{ }^{38}$ conhecida como "Lei Caó", responsável por tipificar os crimes resultantes de preconceito de raça ou de cor, o Estatuto do Idoso, ${ }^{39}$ a Lei Maria da Penha ${ }^{40}$ (Lei $n^{\circ} 11.340 / 06$ ), o Decreto $n^{\circ} 6.040 / 2007,{ }^{41}$ que institui a política nacional de desenvolvimento sustentável dos povos e comunidades tradicionais, o Estatuto da Pessoa com Deficiência, ${ }^{42}$ o Decreto $\mathrm{n}^{\circ} 8.727 / 2016,{ }^{43}$ tornando obrigatório o uso do nome social e do

35 OEA. CONVENCIÓN INTERAMERICANA CONTRA TODA FORMA DE DISCRIMINACIÓN E INTOLERANCIA. Guatemala, 05. jun. 2013.

36 BRASIL. Decreto $n^{\circ} 3.956$ de 08 de outubro de 2001. Promulga a Convenção Interamericana para a Eliminação de Todas as Formas de Discriminação contra as Pessoas Portadoras de Deficiência. Diário Oficial da União, Brasília, 09 out. 2001. Disponível em: http://www.planalto.gov.br/ccivil_03/decreto/2001/d3956.htm. Acesso em: 24 jul. 2019.

37 BRASIL. Decreto $n^{\circ} 9.522$ de 08 de outubro de 2018. Promulga o Tratado de Marraqueche para Facilitar o Acesso a Obras Publicadas às Pessoas Cegas, com Deficiência Visual ou com Outras Dificuldades para Ter Acesso ao Texto Impresso, firmado em Marraqueche, em 27 de junho de 2013. Diário Oficial da União, Brasília, 08 out. 2018. Disponível em: http://www.planalto.gov.br/ccivil_03/_Ato20152018/2018/Decreto/D9522.htm. Acesso em: 23 jul. 2019.

${ }^{38}$ BRASIL. Decreto $n^{\circ} 7.716$ de 05 de janeiro de 1989. Define os crimes resultantes de preconceito de raça ou de cor. Diário Oficial da União, Brasília, 06 jan. 1989. Disponível em: http://www.planalto.gov.br/ccivil_03/decreto/1996/d1973.htm. Acesso em: 23 jul. 2019.

${ }_{39}$ BRASIL. Decreto $\mathrm{n}^{\circ} 10.741$ de 01 de outubro de 2003. Dispõe sobre o Estatuto do Idoso e dá outras providências. Diário Oficial da União, Brasília, 03 out. 2003. Disponível em: http://www.planalto.gov.br/ccivil_03/LEIS/2003/L10.741.htm. Acesso em: 24 jul. 2019.

${ }^{40}$ BRASIL. Decreto $n^{\circ} 11.340$ de 07 de agosto de 2006. Cria mecanismos para coibir a violência doméstica e familiar contra a mulher, nos termos do $\$ 80$ do art. 226 da Constituição Federal, da Convenção sobre a Eliminação de Todas as Formas de Discriminação contra as Mulheres e da Convenção Interamericana para Prevenir, Punir e Erradicar a Violência contra a Mulher; dispõe sobre a criação dos Juizados de Violência Doméstica e Familiar contra a Mulher; altera o Código de Processo Penal, o Código Penal e a Lei de Execução Penal; e dá outras providências. Diário Oficial da União, Brasília, 08 ago. 2006. Disponível em: http://www.planalto.gov.br/ccivil_03/_ato2004-2006/2006/lei/l11340.htm. Acesso em: 24 jul. 2018.

${ }^{41}$ BRASIL. Decreto $n^{\circ} 6.040$ de 07 de fevereiro de 2007. Institui a Política Nacional de Desenvolvimento Sustentável dos Povos e Comunidades Tradicionais. Diário Oficial da União, Brasília, 08 fev. 2007. Disponível em: http://www.planalto.gov.br/ccivil_03/_ato2004-2006/2006/lei/l11340.htm. Acesso em: 24 jul. 2019.

42 BRASIL. Lei $n^{\circ} 13.146$, de 6 de julho de 2015. Institui a Lei Brasileira de Inclusão da Pessoa com Deficiência (Estatuto da Pessoa com Deficiência). Diário Oficial da União, Brasília, 7 jul. 2015.

${ }^{43}$ BRASIL. Decreto $n^{\circ} 8.727$ de 28 de abril de 2016. Dispõe sobre o uso do nome social e o reconhecimento da identidade de gênero de pessoas travestis e transexuais no âmbito da administração pública federal 
ISSN 1981-3694

(DOI): $10.5902 / 1981369435067$

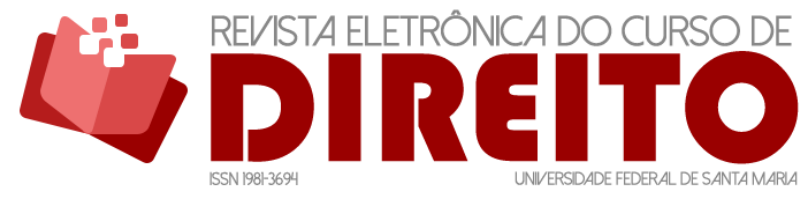

AFIRMAÇÃO E PROMOÇÃO DO DIREITO ÀS DIFERENÇAS DAS PESSOAS COM DEFICIÊNCIA E AS CONTRIBUICCÕES DO SISTEMA INTERAMERICANO DE DIREITOS HUMANOS

Pedro Pulzatto Peruzzo LUCAS SILVA LOPES

reconhecimento de identidade de gênero de travestis e transexuais na administração pública e o Estatuto da Primeira Infância ${ }^{44}$ (Lei $\left.n^{\circ} 13.257 / 2016\right)$, são mais exemplos de afirmação do direito às diferenças.

Apesar de todo amparo legal, ainda se enfrenta a dificuldade de afirmação das diferenças enquanto direito fundamental ante o preconceito arraigado na sociedade. Wolkmer ${ }^{45}$ registra a imprescindibilidade de se "transcender o modelo jurídico individualista, formal e dogmático" no momento em que novos atores sociais, anteriormente marginalizados, estabelecem novas vias para o reconhecimento dos direitos que titularizam por meio de "um processo de lutas específicas e conquistas das identidades coletivas plurais para serem reconhecidos pelo Estado ou pela ordem pública constituída".

Axel Honneth, ${ }^{46}$ em sua tese sobre a luta por reconhecimento, enxerga no direito uma esfera de reconhecimento, ao lado do amor e da estima social. Esse reconhecimento na esfera do direito se realiza primeiro a partir da percepção da simbiose existente entre todos os membros implicados nas relações jurídicas de direitos e deveres recíprocos e, na sequência, após essa percepção, o reconhecimento se desenvolve no sentido do auto respeito na medida em que o processo de individuação tem condições de ocorrer sem o risco de se traduzir em egoísmo, pois o egoísmo não é decorrência da individuação simplesmente, mas da individuação alienada do fato de existir uma simbiose entre todos os membros do corpo social.

O desenrolar dessa luta por reconhecimento na esfera do Direito é fundamental especialmente em razão do autorrespeito. Honneth sustenta que "o autorrespeito é para a relação jurídica o que a autoconfiança era para as relações amorosas". ${ }^{47}$ Direito, nessa linha, tem potencial para promover esse reconhecimento se os profissionais do Sistema de Justiça forem habilitados a compreender a si mesmos como "outro" na sociedade em que vivem (e isso é

direta, autárquica e fundacional. Diário Oficial da União, Brasília, 29 abr. 2016. Disponível em: http://www.planalto.gov.br/ccivil_03/_ato2015-2018/2016/decreto/d8727.htm. Acesso em: 23 jul. 2019. 44 BRASIL. Lei $n^{\circ} 13.257$ de 08 de março de 2016. Dispõe sobre as políticas públicas para a primeira infância e altera a Lei no 8.069, de 13 de julho de 1990 (Estatuto da Criança e do Adolescente), o DecretoLei no 3.689, de 3 de outubro de 1941 (Código de Processo Penal), a Consolidação das Leis do Trabalho (CLT), aprovada pelo Decreto-Lei no 5.452, de 10 de maio de 1943, a Lei no 11.770, de 9 de setembro de 2008, e a Lei no 12.662, de 5 de junho de 2012. Diário Oficial da União, Brasília, 29 abr. 2016. Disponível em: http://www.planalto.gov.br/CCIVil_03/_Ato2015-2018/2016/Lei/L13257.htm. Acesso em: 24 jul. 2019.

${ }^{45}$ WOLKMER, Antonio Carlos; LEITE, J. R. M. (Org.). Os 'novos' direitos no Brasil - Natureza e Perspectivas - Uma visão básica das novas conflituosidades jurídicas. 2. ed. São Paulo: Saraiva, 2012. v. 1. p. 32-35.

${ }^{46}$ Honneth, Axel. Luta por reconhecimento: a gramática moral dos conflitos sociais. Tradução de Luiz Repa. São Paulo: 34, 2003. p. 18.

47 Honneth, Axel. Luta por reconhecimento: a gramática moral dos conflitos sociais. Tradução de Luiz Repa. São Paulo: 34, 2003. p. 194. 
ISSN 1981-3694

(DOI): $10.5902 / 1981369435067$

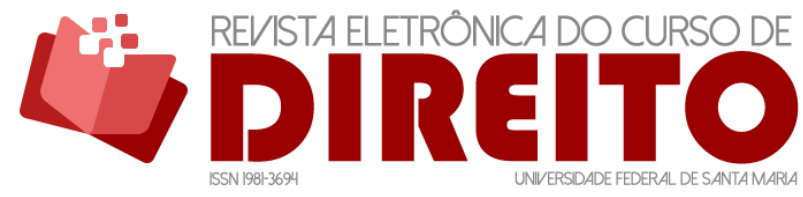

AFIRMAÇÃO E PROMOÇÃO DO DIREITO ÀS DIFERENÇAS DAS PESSOAS COM DEFICIÊNCIA E AS CONTRIBUICCÕES DO SISTEMA INTERAMERICANO DE DIREITOS HUMANOS

Pedro Pulzatto Peruzzo LUCAS SILVA LOPES

mais viável do que esperar a compreensão a priori do outro como diferente que deve ser respeitado em suas diferenças). É exatamente essa compreensão de si mesmo enquanto “outro" em relação aos outros por aqueles que criam, aplicam e interpretam o Direito que permite ao Direito reconhecer as diferenças nos casos concretos e, ao invés de reproduzir a violência, promover a composição respeitosa dos conflitos sociais concretamente.

A afirmação da diferença enquanto direito humano surge do fortalecimento das diferentes pautas construídas por grupos minoritários que se viram prejudicados pela disseminação de discursos políticos, midiáticos e instrumentos normativos com vistas à homogeneização da identidade. ${ }^{48}$ Em pertinente análise, Sousa ${ }^{49}$ registra que tais discursos ainda encontram força pelo fato do sujeito de direito moderno ter sido constituído sobre fatores políticos, jurídicos filosóficos e sociais peculiares ao ocidente, apresentando como diretriz a ideia do ser humano enquanto ente abstrato, sem diferença substancial.

Tratar todo mundo como igual não seria um problema se essa igualdade estivesse fincada no fato concreto de que todos somos diferentes. O problema é, portanto, o fato de considerar a igualdade como resultado de uma homogeneização que, em última instância, é realizada com muita eficiência pelo modo de produção que plasma todos os indivíduos em categorias fechadas, ou seja, como proprietários, como empregados ou como mercadoria. 0 rompimento da ideia de um sujeito universal abstrato, calcado em uma única diretriz de normalidade, se dá após uma série de críticas culturais baseadas na alteridade e da ocupação do espaço público por novos sujeitos sociais contrários a essas políticas assimilacionistas reivindicando "novos direitos de cidadania" e "políticas culturais". 50

\footnotetext{
${ }^{48}$ A título de exemplo, temos no ordenamento jurídico brasileiro o Estatuto do Índio - Lei 6.001/73 -, ao estabelecer em seu artigo $1^{\circ}$ como plano de ação governamental dirigida aos povos indígenas sua integração "progressiva e harmoniosamente, à comunhão nacional". (BRASIL. Lei no 6.001/73 de 19 de dezembro de 1973. Dispõe sobre o Estatuto do Índio. Diário Oficial da União, Brasília, 21. dez. 1973. Disponível em: http://www.planalto.gov.br/ccivil_03/Leis/L6001.htm. Acesso em 24. jul. 2019.) Do mesmo modo, tem-se estabelecido o debate acerca da cirurgia plástica com vistas à alteração dos traços faciais das pessoas com Síndrome de Down e das razões de sua existência para fins eminentemente estéticos e não-terapêuticos e sobre o fato de, se neste último caso, há realmente manifestação de vontade livre de qualquer vício ou pressão social.

Cf. https://veja.abril.com.br/saude/a-vida-repaginada-dos-portadores-de-sindromes-geneticas/. Acesso em 23 jul. 2019.

49 SOUSA, Rosinaldo S. Direitos Humanos através da História recente em uma Perspectiva Antropológica.In Roberto Kant de Lima; Regina Novais. (Org.). Antropologia e Direitos Humanos. Niterói: EdUFF, v. 30, 2002. p. 58.

50 SOUSA, Rosinaldo S. Direitos Humanos através da História recente em uma Perspectiva Antropológica.In Roberto Kant de Lima; Regina Novais. (Org.). Antropologia e Direitos Humanos. Niterói: EdUFF, v. 30, 2002. p. 56.
} 
ISSN 1981-3694

(DOI): $10.5902 / 1981369435067$

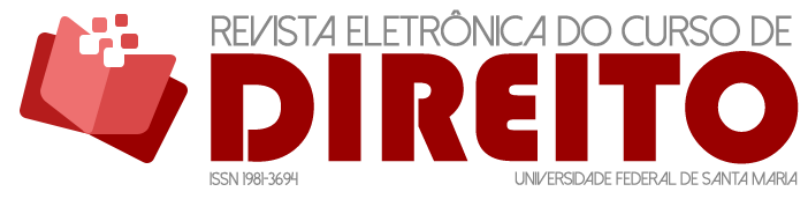

AFIRMAÇÃO E PROMOÇÃO DO DIREITO ÀS DIFERENÇAS DAS PESSOAS COM DEFICIÊNCIA E AS CONTRIBUICCÕES DO SISTEMA INTERAMERICANO DE DIREITOS HUMANOS

Pedro Pulzatto Peruzzo LUCAS SILVA LOPES

Destarte, é importante analisar os impactos positivos e negativos que os discursos acerca dos direitos humanos assumem frente ao direito às diferenças, ora como instrumentos hegemônicos de dominação, ora como contra hegemônicos. ${ }^{51}$ Joaquin Herrera Flores, ${ }^{52}$ por exemplo, ao enunciar a existência de duas concepções para análise dos direitos humanos, a abstrata e a localista, aponta ambas as propostas como incoerentes, visto que se prestam à elaboração de discursos reducionistas da realidade legitimando políticas excludentes.

Rouanet ${ }^{53}$ trabalha com bastante precisão essa distinção e esclarece que não se trata simplesmente de excluir qualquer relativismo ou qualquer universalismo. A proposta seria a compreensão de que o relativismo foi relevante para a superação do evolucionismo cultural, onde as manifestações culturais eram hierarquizadas em escalas evolutivas, enquanto o universalismo foi relevante se compreendido não como um ponto de partida (etnocentrismo), mas como um ponto de chegada, cabendo aqui uma alusão a uma proposta de Herrera Flores em relação ao universalismo de chegada:

O que negamos é considerar o universal como um ponto de partida ou um campo de desencontros. Ao universal há que se chegar - universalismo de chegada ou de confluência - depois (não antes) de um processo conflitivo, discursivo de diálogo (...). ${ }^{54}$

Assim, afirmamos que a proposta deste trabalho não é a homogeneidade, mas o entendimento e a convivência menos violenta, e isso não exige um universal homogêneo, mas um universal onde caibam todos em suas diferenças, mesmo que em paralelo. ${ }^{55}$

Neste sentido, a cooperação jurídica no âmbito do Direito Internacional dos Direitos Humanos tem acontecido como um processo que tem reunido esforços importantes para a continuidade da afirmação das diferenças como um direito humano e o Sistema Interamericano de Direitos Humanos tem dado importantes contribuições nesse sentido. Sobre esse assunto discorreremos no tópico a seguir.

\footnotetext{
${ }^{51}$ SANTOS, Boaventura de Sousa. Por uma concepção multicultural de direitos humanos. Revista Crítica de Ciências Sociais. $N^{\circ} 48,1997$. p.18.

52 Cf. FLORES, Joaquin Herrera. Direitos humanos, interculturalidade e racionalidade de resistência. Sequiência - Estudos Jurídicos e Políticos. vol. 23, no 44. 2002. Acesso em: https://periodicos.ufsc.br/index.php/sequencia/article/view/15330/13921. Acesso em: 23. jul. 2019. ${ }^{53}$ ROUANET, S. P. Mal-estar na modernidade: ensaios. São Paulo: Companhia das Letras, 1993. p. 274.

54 FLORES, Joaquin Herrera. Direitos humanos, interculturalidade e racionalidade de resistência. Sequiência - Estudos Jurídicos e Políticos. vol. 23, no 44. 2002. p. 9. Acesso em: https://periodicos.ufsc.br/index.php/sequencia/article/view/15330/13921. Acesso em: 23. jul. 2019.

${ }_{55} \mathrm{Cf}$. PERUZZO, P. P. Direito à consulta prévia aos povos indígenas no Brasil. Direito \&Praxis. vol.8. n. 4. 2017. Disponível em: https://www.e-publicacoes.uerj.br/index.php/revistaceaju/article/view/24631. Acesso em: 23 jul. 2019.
} 


\section{A AFIRMAÇÃO DO MODELO SOCIAL DA DEFICIÊNCIA PELA CORTE INTERAMERICANA DE DIREITOS HUMANOS}

Ainda hoje a relação entre o direito interno e o direito internacional é objeto de muitas discussões acadêmicas e, especialmente, jurisprudenciais, apesar da reflexão e produção teórica sistemática sobre o assunto desde o início do século XX, com a consolidação da Liga das Nações e a criação da Organização Internacional do Trabalho, ambas em 1919.

Apesar da relevância desse esforço inicial para a regulamentação de temas de relevo em âmbito internacional após a Primeira Guerra Mundial, foi o processo que se consolidou após a Segunda Guerra, com a criação da Organização das Nações Unidas ${ }^{56}$ e alguns sistemas regionais de Direitos Humanos, ${ }^{57}$ que de fato fortaleceu o projeto de governança global pautado no Direito Internacional dos Direitos Humanos, como conjunto de regras e princípios orientadores das relações internacionais com o objetivo de promoção da paz com base num dever geral de cooperação. Nessa linha, tanto os direitos e garantias enunciados em tratados e convenções, como os sistemas de proteção neles previstos, são responsáveis pelo corpo iuris do Direito Internacional dos Direitos Humanos. ${ }^{58}$

Internamente, tivemos avanços importantes na solução dos embates acadêmicos e jurisprudenciais relativos ao tema com a inserção, pela Emenda Constitucional n. 45/04, do parágrafo $3^{\circ}$ no artigo $5^{\circ}$ da Constituição Federal, atribuindo estatuto de emenda constitucional aos tratados e convenções internacionais sobre direitos humanos aprovados, em cada Casa do Congresso Nacional, em dois turnos, por 3/5 dos votos dos respectivos membros. Essa Emenda

\footnotetext{
${ }^{56}$ BRASIL. Decreto $n^{\circ} 19.841$ de 22 de outubro de 1945. Promulga a Carta das Nações Unidas, da qual faz parte integrante o anexo Estatuto da Corte Internacional de Justiça, assinada em São Francisco, a 26 de junho de 1945, por ocasião da Conferência de Organização Internacional das Nações Unidas. Coleção de Leis do Brasil de 1945, Rio de Janeiro, 22 out. 1945. Disponível em: http://www.planalto.gov.br/ccivil_03/decreto/1930-1949/D19841.htm. Acesso em: 24 jul. 2019.

${ }^{57}$ A Carta da Organização dos Estados Americanos foi assinada em 30 de abril de 1948 e incorporada pelo Decreto 30.544/52, além de afirmar que dentro das Nações Unidas a Organização dos Estados Americanos constitui um organismo regional, também preve a Comissão Interamericana de Direitos Humanos, principal órgão de recebimento de denúncias do Sistema Interamericano. Também em 1950 foi adotada, pelo Conselho da Europa, a Convenção Europeia de Direitos Humanos, organizando o Sistema Europeu de Direitos Humanos. Vale lembrar que esses sistemas de proteção possuem caráter complementar e não excludente, haja vista a existência de peculiaridades quanto à sua natureza, efeitos jurídicos, destinatários, beneficiários, âmbitos de aplicação e mecanismos de controle e supervisão. (Cf. TRINDADE, Antônio Augusto Cançado. A proteção internacional dos direitos humanos e o Brasil. Brasília: Universidade de Brasília).

${ }^{58}$ RAMOS, André de Carvalho. Curso de direitos humanos. 1. ed. São Paulo: Saraiva, 2014. p. 137.
} 
ISSN 1981-3694

(DOI): $10.5902 / 1981369435067$

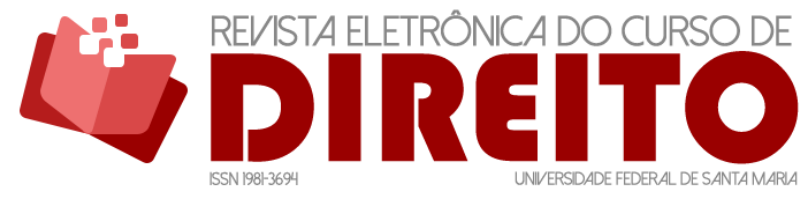

AFIRMAÇÃO E PROMOÇÃO DO DIREITO ÀS DIFERENÇAS DAS PESSOAS COM DEFICIÊNCIA E AS CONTRIBUICCÕES DO SISTEMA INTERAMERICANO DE DIREITOS HUMANOS

Pedro Pulzatto Peruzzo LUCAS SILVA LOPES

buscou pacificar as discussões sobre o estatuto hierárquico desses documentos no ordenamento e em 2008 o Supremo Tribunal Federal, no RE 466343, consolidou o entendimento no sentido de que os tratados e convenções de direitos humanos que não fossem aprovados pelo quórum do parágrafo $3^{\circ}$ teriam estatuto supralegal, ficando abaixo da Constituição e acima das leis ordinárias e complementares.

A cooperação jurídica internacional em direitos humanos manifesta-se, portanto, na dinâmica e na própria finalidade dos sistemas universal e regionais, ao estabelecerem mecanismos de promoção e proteção aos direitos humanos em harmonia com os sistemas jurídicos internos dos Estados nacionais.

Os organismos internacionais de direitos humanos vêm permitindo que minorias excluídas e oprimidas no âmbito nacional assumam posição de igualdade perante o Estado violador de direitos humanos em nível global. A cooperação jurídica internacional em direitos humanos assume relevância na medida em que as avaliações que o Poder Público faz de suas omissões e ações violadoras de direitos humanos normalmente encobrem muitas questões relevantes e estruturais que são expostas com muito mais clareza nos foros internacionais de fiscalização e discussão sobre o alcance dos direitos humanos. Sem contar que as decisões e recomendações feitas por esses organismos têm um potencial muito maior de constranger os Estados a darem cumprimento no âmbito interno. ${ }^{59}$

Reconhecer que a desigualdade social e a fragilidade da consolidação democrática tem relação direta com o cenário de violação de direitos humanos, assim como a ausência de espaço de diálogo entre a sociedade civil e seus governantes no âmbito nacional, é fundamental para compreender o Sistema Interamericano como um foro onde são encontrados mecanismos com maior capacidade para superar esses problemas e, portanto, garantir de fato a promoção dos direitos humanos, ou ao menos o acesso justo a um organismo deliberativo de natureza jurídica. Nesse sentindo, Bernardes afirma a importância de organizações internacionais com o mesmo cunho do SIDH, haja vista que nesses espaços "valores são construídos e disseminados, práticas

\footnotetext{
${ }^{59}$ Exemplo disso foram as políticas públicas implementadas em razão da condenação do Brasil pelo Comitê sobre a Eliminação de todas as formas de Discriminação contra a Mulher no caso Alyne da Silva Pimentel. Uma dessas políticas foi a Rede Cegonha, com o objetivo de priorizar a melhoria do atendimento ao parto na rede pública de saúde, com adesão de estados e municípios. Além disso, em 2013 foi publicada a Portaria $n^{\circ} 1.020(29 / 05 / 2013)$ que institui as Diretrizes Nacionais de Atenção à Saúde da Gestante de Alto Risco, Recém-Nascido de Risco e Puérpera de Risco e define os critérios para a implantação e habilitação dos serviços de atenção à gestação de alto risco, em conformidade com a Rede Cegonha. Cf. CEDAW. Alyne da Silva Pimentel Teixeira v. Brazil, CEDAW/C/49/D/17/2008, August 10, 2011, Disponível em: http://www.worldcourts.com/cedaw/eng/decisions/2011.07.25_da_Silva_Pimentel_v_Brazil.pdf. Acesso em 30 mar. 2019.
} 
tradicionais enraizadas são questionadas e ressignificadas e repertórios de ação são construídos e ampliados". 60

Abramovich ${ }^{61}$ destaca que o Sistema Interamericano tem desempenhado importante papel de ativismo transnacional ao estabelecer diálogo com a sociedade civil local para emissão de relatórios que irão influenciar na elaboração de princípios, de standards jurídicos e principalmente na elaboração de políticas públicas destinadas à promoção dos direitos humanos.

A CIDH avalia fundamentalmente a existência de um padrão ou "modelo de conduta sistemática" na resposta do Estado, que expressa a seu juízo uma forma de tolerância pública com a situação de violência denunciada não apenas em prejuízo da vítima, mas em relação a outros casos idênticos ou com características comuns. 0 enfoque, como dissemos, vai mais além da situação particular da vítima individual, pois se projeta para a avaliação da situação de discriminação e subordinação de um grupo social determinado. ${ }^{62}$

Característica fundamental do Sistema Interamericano é o fato de existir a possibilidade de peticionamento individual à Comissão (art. 44 da Convenção). Para grupos minoritários que normalmente têm seus direitos violados de forma reiterada em razão das dificuldades institucionais para acesso à Justiça, poder contar com um órgão internacional para denunciar diretamente violações de direitos humanos é algo extremamente relevante. Todavia, não se resume a isso o papel do SIDH, uma vez que, além de admitir o peticionamento individual, o SIDH tem se mostrado muito mais aberto às múltiplas vozes que, muitas vezes, são silenciadas pelas políticas hegemônicas e homogeneizantes dos Estados nacionais.

No que diz respeito às pessoas com deficiência, a análise de julgados da Corte Interamericana de Direitos Humanos torna possível traçar duas diretrizes adotadas pelo órgão com vistas ao rompimento das violações estruturais de direitos humanos, a saber: (I) a primeira que considera que a prestação positiva dos Estados-membros na proteção e promoção dos

60 BERNARDES, M. N. Sistema Interamericano de Direitos Humanos como Esfera Pública Transnacional: Aspectos Jurídicos e Políticos da Implementação de Decisões Internacionais. SUR -Revista Internacional de Direitos Humanos. vol. 11., n. 15, 2011. p. 139. Disponível em: https://sur.conectas.org/sistemainteramericano-de-direitos-humanos-como-esfera-publica-transnacional/. Acesso em: 23 jul. 2019.

${ }_{61}$ ABRAMOVICH, Víctor. Das violações em massa aos padrões estruturais: novos enfoques e clássicas tensões no sistema interamericano de direitos humanos. São Paulo: SUR - Revista Internacional de Direitos Humanos, 2009. p. 14-23. Disponível em: http://sur.conectas.org/wpcontent/uploads/2017/11/sur11-port-debora-diniz-livia-barbosa-e-wederson-rufino-dos-santos.pdf. Acesso em: 23 jul. 2019.

${ }^{62}$ ABRAMOVICH, Víctor. Das violações em massa aos padrões estruturais: novos enfoques e clássicas tensões no sistema interamericano de direitos humanos. São Paulo: SUR - Revista Internacional de Direitos Humanos, 2009. p. 10. Disponível em: http://sur.conectas.org/wpcontent/uploads/2017/11/sur11-port-debora-diniz-livia-barbosa-e-wederson-rufino-dos-santos.pdf. Acesso em: 23 jul. 2019. 
ISSN 1981-3694

(DOI): $10.5902 / 1981369435067$

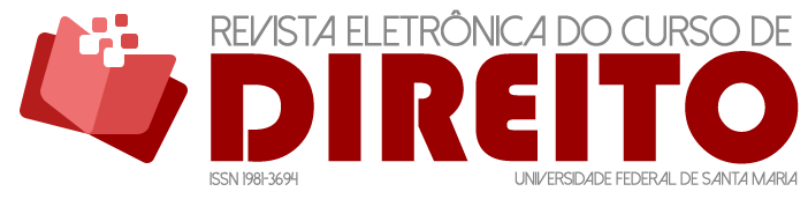

AFIRMAÇÃO E PROMOÇÃO DO DIREITO ÀS DIFERENÇAS DAS PESSOAS COM DEFICIÊNCIA E AS CONTRIBUICCÕES DO SISTEMA INTERAMERICANO DE DIREITOS HUMANOS

Pedro Pulzatto Peruzzo LUCAS SILVA LOPES

direitos humanos decorre da obrigação de respeitar direitos presentes na Convenção Americana, principalmente de grupos que são vítimas de violações sistemáticas de direitos humanos, e (II) a segunda, que trabalha com a interpretação evolutiva dos instrumentos internacionais e com a harmonização do princípio da igualdade com a garantia de não-discriminação como métodos hermenêuticos aplicados na garantia e promoção dos direitos de grupos social e culturalmente diferenciados, tal como a adoção do modelo social da deficiência.

Dois casos são paradigmáticos para essa análise, quais sejam Damião Ximenes Lopes vs Brasil (2006) e Caso Furlan e Familiares vs Argentina (2012). Em ambos os casos a Corte afirmou, com base no modelo social e na interpretação evolutiva dos direitos humanos, a existência e a necessidade de superar os padrões e as múltiplas facetas das violações de direitos humanos da pessoa com deficiência. A forma como a Corte abordou a deficiência nesses dois casos avançou, e muito, em relação à forma como o Direito interno vinha abordando a questão.

No Brasil, apesar de existirem diretrizes para políticas públicas de acessibilidade (parágrafo $2^{\circ}$ do artigo 227, da Constituição, a Convenção da ONU sobre os Direitos da Pessoa com Deficiência, incorporada em 2009, e a Lei Brasileira de Inclusão, de 2015), ainda hoje os gestores públicos e magistrados não sabem lidar com a deficiência. A exemplo, o prefeito da cidade de São Paulo, João Dória, disse, em um dos seus discursos, que iria doar seu salário de prefeito para a AACD que, segundo ele, seria uma associação para crianças defeituosas. ${ }^{63}$ Além do João Dória, em entrevista à Globo News, na primeira semana na presidência do Supremo Tribunal Federal, a ministra Cármen Lúcia disse que a sociedade poderia esperar o empenho dos integrantes do tribunal, porque eles não eram autistas, e sim cidadãos. ${ }^{64}$

No que diz respeito aos casos em análise, a Corte Interamericana afirmou a obrigação dos Estados-membros de respeitarem os direitos e garantias resguardados nos documentos internacionais mediante prestações positivas, o que afirma que a deficiência é uma consequência do ambiente (modelo social), bem como destacou a necessidade da tomada de medidas específicas e emergenciais para grupos em maior situação de vulnerabilidade.

No caso de Damião Ximenes Lopes, primeiro caso de deficiência mental analisado pela Corte, foi decidido o seguinte:

\footnotetext{
${ }^{63} \mathrm{Cf}$. https://www.deficienteciente.com.br/doria-comete-gafe-e-chama-aacd-de-associacao-paracriancas-defeituosas.html. Acesso em 23 jul. 2019.

${ }^{64} \mathrm{Cf}$. https://oglobo.globo.com/brasil/carmen-lucia-se-desculpa-com-autistas-por-comentario-ementrevista-20138543. Acesso em 23 jul. 2019.
} 
Não obstante, a Corte considera pertinente analisar certos aspectos relativos à violação dos direitos consagrados nos artigos 4 e 5 da Convenção neste caso, já que esta é a primeira vez que o Tribunal tem a oportunidade de se pronunciar sobre a violação dos direitos de uma pessoa portadora de deficiência mental. A Corte analisará o tema sob duas perspectivas: A) os direitos das pessoas portadoras de deficiência mental; e B) os deveres do Estado com relação a essas pessoas. ${ }^{65}$

Após ser internado em instituição psiquiátrica, submetido a condições de higiene subumanas, Damião Ximenes foi morto por espancamento sofrido no interior do estabelecimento. Dado contexto é tomado como oportunidade pela Corte Interamericana para tecer críticas a uma espécie de violência estrutural voltada à pessoa com deficiência mental, qual seja o modelo médico asilar-manicomial, que carrega uma forte carga de preconceito e estigma, trazendo para o debate a harmonização do princípio da igualdade com a nãodiscriminação na interpretação evolutiva. ${ }^{66}$

Nesse caso, a Corte ainda afirma que a deficiência mental por si só não é sinônimo de incapacidade e que o uso da força em tratamentos psiquiátricos deve possuir caráter

65 CORTE IDH, Caso Ximenes Lopes Vs Brasil. Mérito, Reparações e Custas. Sentença de 4 de julho de
2006 parágrafo $\quad 123 . \quad 149 . \quad$ Serie $\quad N^{\circ} \quad$ Disponível em: http://www.corteidh.or.cr/docs/casos/articulos/seriec_149_por.pdf. Acesso em 23 jul. 2019.

66 A Corte tem utilizado a "interpretação evolutiva dos direitos humanos" para o reconhecimento de outros modos de existência que são ignorados, ou até mesmo criminalizados. Dado princípio tem fundamento no artigo 29 da Convenção Americana, que estabelece diretrizes de interpretação que vedam qualquer exercício hermenêutico com tendência ou efeito de suprimir, impedir exercício de direitos, liberdades ou garantias inerentes ao ser humano ou outro documento internacional que verse sobre direitos humanos: "Em outras oportunidades, este Tribunal salientou que os tratados de direitos humanos são instrumentos vivos, cuja interpretação tem de acompanhar a evolução dos tempos e as condições de vida do momento. Essa interpretação evolutiva é compatível com as regras gerais de interpretação estabelecidas no artigo 29 da Convenção Americana, bem como na Convenção de Viena sobre o Direito dos Tratados. Nesse sentido, esta Corte tem afirmado que, ao interpretar um tratado, não só se levam em conta os acordos e instrumentos com ele formalmente relacionados (artigo 31.2 da Convenção de Viena), mas também o sistema no qual se inscreve (artigo 31.3 do mesmo instrumento)". (CORTE IDH. Caso "Povo Indígena Kichwa de Sarayakuvs Equador”. Sentença de 27 de julho de 2012, parágrafo 161. Disponível em: http://corteidh.or.cr/docs/casos/articulos/seriec_245_esp.pdf. Acesso em 23 jul. 2019.) Da mesma forma, a $\mathrm{CIDH}$ tem lançado mão de dado instrumento no contexto de luta dos povos indígenas, tendo a tendência dos Estados nacionais em operarem a interpretação restritiva de direitos dos povos indígenas com vistas à defesa da propriedade privada. No entanto, ao utilizar desse recurso hermenêutico afirma-se que o artigo 21 da Convenção Americana de Direitos Humanos, que versa sobre direito à propriedade privada, também promove a defesa do direito à propriedade comunal dos povos indígenas. Dada proteção é legitimada pelo (e com vistas) ao reconhecimento das relações culturais que os povos indígenas desenvolvem com a terra, tanto seu caráter de subsidio material como sacro, que transcendem àquelas relações a que estamos habituados a vivenciar no âmbito do direito civil. MELO, Mario. Últimos avanços na justiciabilidade dos direitos indígenas no Sistema Interamericano de Direitos Humanos. São Paulo: SUR - Revista Internacional dos Direitos Humanos, 2006. p. 26. Disponível em: https: / / sur.conectas.org/ultimos-avancos-na-justiciabilidade-dos-direitos-indigenas-no-sistemainteramericano-de-direitos-humanos/. Acesso em: 23 jul. 2019. 
excepcional e, quando necessário, executado por profissionais competentes, com vistas à preservação da integridade física do paciente.

Outro ponto de relevo é o destaque dado pela Corte e Comissão Interamericana de Direitos Humanos à autonomia da vontade do paciente, que deve ser respeitada mesmo no interior de instituições psiquiátricas, haja vista que, considerando o modelo social, os entraves atribuídos à lesão mental ou cognitiva têm origem na ausência de esforços estatais e sociais para a criação de canais de comunicação e/ou linguagens voltadas a essas pessoas:

A falta de uma linguagem concernente especificamente às pessoas portadoras de deficiência mental nos instrumentos internacionais de direitos humanos dificulta a aplicação dessas normas a tais pessoas. Como resultado de sua marginalização, as pessoas com deficiências mentais não contam com os recursos nem com o reconhecimento necessários, para formar organizações que defendam seus direitos nacional e internacionalmente. ${ }^{67}$

No caso Furlan, a Corte decidiu na mesma linha demonstrando uma consolidação do entendimento e afirmação do modelo social e da interpretação evolutiva:

A Corte Interamericana considera que toda pessoa que se encontre em situação de vulnerabilidade é titular de uma proteção especial, em virtude dos deveres especiais cujo cumprimento por parte do Estado é necessário para atender às obrigações gerais de respeito e garantia dos direitos humanos. A Corte reitera que não basta que os Estados se abstenham de violar os direitos, mas que é imperativa a adoção de medidas positivas, determináveis em função das necessidades particulares de proteção do sujeito de direito, seja por sua condição pessoal, seja pela situação específica em que se encontre, como a deficiência. ${ }^{68}$

A vítima desse caso adquiriu lesões que, agravadas pela falta de assistência médica para sua reabilitação, desencadearam a deficiência cognitiva, impondo dificuldades no estabelecimento de relações na dinâmica familiar e laboral, culminando, inclusive, em uma tentativa de suicídio. Ponto principal do debate travado nesse caso foi a omissão estatal na prestação de serviços e políticas públicas efetivas no processo de reabilitação e inclusão. Nesta oportunidade, a Corte aplicou o modelo social da deficiência com a proposta de estabelecer o

${ }^{67}$ CORTE IDH, Caso Ximenes Lopes Vs Brasil. Mérito, Reparações e Custas. Sentença de 4 de julho de 2006, parágrafo 123. Serie $\mathrm{N}^{\circ} 149 . \quad$ p. $11 . \quad$ Disponível em: http:// www.corteidh.or.cr/docs/casos/articulos/seriec_149_por.pdf. Acesso em 23 jul. 2019.

68 CORTE IDH, Caso “Furlan e familiares Vs. Argentina”. Sentença de 31 de agosto de 2012, parágrafo 114. Disponível em: http://www.corteidh.or.cr/docs/casos/articulos/seriec_246_esp.pdf. Acesso em 23 jul. 2019. 
nexo causal entre a lesão sofrida por Furlan e a negligência do Estado argentino em seu processo de reabilitação e inclusão, culminando na deficiência e, por conseguinte, em todas as dificuldades enfrentadas por aquele:

A este respeito, a Corte observa que nas mencionadas Convenções se tem em conta o modelo social para abordar a deficiência, o que implica que a deficiência não se define exclusivamente pela presença de uma deficiência física, mental, intelectual ou sensorial, mas que se interrelaciona com as barreiras ou limitações existentes socialmente para que as pessoas possam exercer seus direitos de maneira efetiva. Os tipos de limites ou barreiras que as pessoas com diversidade funcional comumente encontram na sociedade são, entre outras, barreiras físicas ou arquitetônicas, comunicativas de atitudes ou socioeconômicas.[...] Isso implica que as medidas de reparação não se concentram exclusivamente em medidas de reabilitação de tipo médico, mas incluem medidas que ajudem a pessoa com deficiência a enfrentar as barreiras ou limitações impostas, com o objetivo de que esta pessoa possa "alcançar e manter a máxima independência, capacidade física, mental, social e vocacional, e a inclusão e participação plena em todos os aspectos da vida.

Em ambos os casos a Corte assevera que o Estado possui o dever de cuidado em relação a todas as pessoas, condenando a inércia Estatal ante a existência de uma vulnerabilidade de fato de dado grupo social, mesmo que existente a equiparação de direitos no campo jurídico normativo. ${ }^{69}$

Deste modo, reconhecendo a vulnerabilidade fática de Furlan, considerando a não prestação de serviços de reabilitação competentes a sua recuperação, a Corte reconheceu, enquanto medida de reparação, o "dano ao projeto de vida", haja vista que a configuração e agravamento de sua deficiência resultaram em dificuldades para atingir sua realização plena na esfera profissional e familiar, conforme asseverado pelo órgão julgador:

Com respeito ao suposto "dano às relações de vida" alegado pelos representantes no caso de Sebastián Furlan, tomando em conta o conteúdo da alegação, a Corte interpreta esta expressão em relação ao denominado dano ao "projeto de vida", que se refere à realização integral da pessoa afetada, considerando sua vocação, aptidões, circunstâncias, potencialidades e aspirações, que the permitem fixar razoavelmente determinadas expectativas e alcançá-las. O projeto de vida se expressa nas expectativas de desenvolvimento pessoal, profissional e familiar possíveis em condições normais. Esta Corte indicou que o "dano ao projeto de vida" implica a perda ou o grave prejuízo de oportunidades de desenvolvimento pessoal, de forma irreparável ou muito dificilmente reparável. Este dano se deriva das limitações sofridas por uma pessoa para se relacionar e gozar de seu ambiente pessoal, familiar ou social, por lesões graves de tipo físico, mental,

69 YEPES, Rodrigo Uprimny; DUQUE, Luz María Sánchez. Convención Americana sobre Derechos Humanos - Comentario. Berlín: Konrad AdenauerStiftung, 2014. p. 587-588. 
ISSN 1981-3694

(DOI): $10.5902 / 1981369435067$

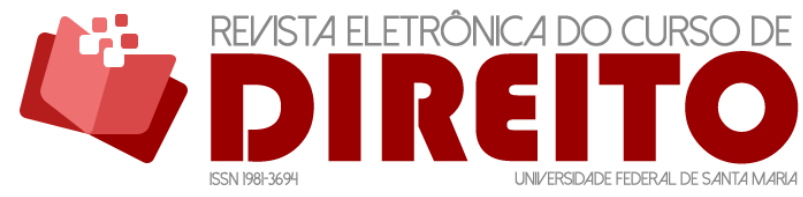

AFIRMAÇÃO E PROMOÇÃO DO DIREITO ÀS DIFERENÇAS DAS PESSOAS COM DEFICIÊNCIA E AS CONTRIBUICCÕES DO SISTEMA INTERAMERICANO DE DIREITOS HUMANOS

Pedro Pulzatto Peruzzo LUCAS SILVA LOPES

psicológico ou emocional. A reparação integral do dano ao "projeto de vida" geralmente requer medidas reparatórias que vão além de uma mera indenização monetária, consistentes em medidas de reabilitação, satisfação e não repetição. $^{70}$

Apenas para registrar o alinhamento do sistema interamericano com o sistema global, o modelo social e a interpretação evolutiva dos direitos humanos também foram utilizados pelo Comitê dos Direitos da Pessoa com Deficiência da ONU, no caso H. M. Vs. Suécia, ${ }^{71}$ levado à apreciação do órgão pela comunicação de $n^{\circ}$ 03/2011, versando acercada legalidade da restrição imposta pelos setores administrativos da cidade de Örebro, na Suécia, à H.M, que pretendia construir uma piscina no quintal de sua residência para tratamento da síndrome de Ehlers-Danlos (conhecida como "Síndrome do Homem-Elástico").

No caso, o Estado alegou a incompatibilidade do projeto com o planejamento urbano da cidade, afirmando que se a construção fosse permitida exclusivamente à vítima e vedada aos demais munícipes, ocorreria uma discriminação em razão da deficiência, afrontando o artigo 5 da Convenção da ONU sobre os Direitos da PCD ${ }^{72}$.

O Comitê dos Direitos da Pessoa com Deficiência afastou o argumento estatal apontando a imprescindibilidade da harmonização da igualdade e da não-discriminação, não os concebendo como diretrizes axiológicas excludentes, sendo possível observar a semelhança entre a estrutura lógica utilizada pelo Comitê e a exposta pela Corte.

Nessa linha, pudemos identificar um alinhamento entre os organismos internacionais, em especial na Corte Interamericana, referente aos entendimentos norteadores do modelo social que entende a deficiência como fruto da estrutura social discriminatória e da vulnerabilidade social de alguns grupos. A Corte aponta a desigualdade social como importante fator no desencadeamento de deficiências, haja vista que, em determinados contextos predomina a escassez de recursos e de esforços destinados à prevenção e tratamento de doenças ou outros eventos incapacitantes. ${ }^{73}$

\footnotetext{
${ }^{70}$ CORTE IDH, Caso "Furlan e familiares Vs. Argentina". Sentença de 31 de agosto de 2012, parágrafo 285. Disponível em: http://www.corteidh.or.cr/docs/casos/articulos/seriec_246_esp.pdf. Acesso em 23 jul. 2019.

71 ONU. Comitê sobre os Direitos das Pessoas com Deficiência. Comunicação n $3 / 2011$, Caso H. M. Vs. Suécia, CRPD/C/7/D/3/2011, 19 de abril de 2012, par. 8.3.

72 Artigo 5, item 1: Os Estados Partes reconhecem que todas as pessoas são iguais perante e sob a lei e que fazem jus, sem qualquer discriminação, a igual proteção e igual benefício da lei.

73 Dados das Organizações das Naçõ̃es Unidas informam que $80 \%$ das pessoas com deficiência no mundo vivem em países em desenvolvimento e, ainda, aponta que a pessoa que convive com alguma deficiência tem seu custo de vida triplicado, apresentando relação importante entre a desigualdade social e a
} 
ISSN 1981-3694

(DOI): $10.5902 / 1981369435067$

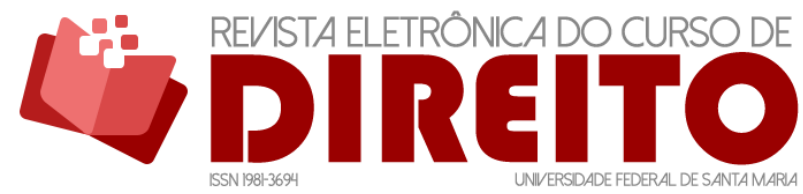

AFIRMAÇÃO E PROMOÇÃO DO DIREITO ÀS DIFERENÇAS DAS PESSOAS COM DEFICIÊNCIA E AS CONTRIBUICCÕES DO SISTEMA INTERAMERICANO DE DIREITOS HUMANOS

Pedro Pulzatto Peruzzo LUCAS SILVA LOPES

De certo, a concepção dos direitos humanos enquanto instrumentos vivos e passíveis de ressignificação (interpretação evolutiva) não implica avanços somente nas pautas das pessoas com deficiência, mas também de todo e qualquer grupo ou indivíduo vítima de violações estruturais em razão das diferenças. Exemplo disso foi o caso AtalaRiffo e Crianças Vs. Chile ${ }^{74}$ que versava acerca da retirada da guarda das filhas Sra. Riffo sob a justificativa de que sua orientação sexual representaria perigo de dano às menores. No caso, a Corte asseverou que a postura adotada pelas instâncias judiciárias do Estado Chileno configuraria discriminação motivada por orientação sexual em desconformidade com o artigo 1.1 da Convenção Americana, mesmo que dada modalidade de violação não estivesse incluída no rol taxativo daquele dispositivo (interpretação evolutiva).

Nesse sentido, a interpretação evolutiva e a consolidação do modelo social, somadas à abertura do SIDH a indivíduos e grupos de indivíduos que encontram dificuldades para acessar a Justiça no âmbito doméstico, afirmam a existência de barreiras que impedem grupos social ou culturalmente diferenciados acessarem à Justiça e forçam os Estados a tomarem as medidas necessárias para a superação desses obstáculos.

Essas concepções, portanto, não apenas proporcionam uma ampliação do sentido dos direitos para que dentro deles seja albergado um número maior de pessoas, mas também possibilita uma compreensão mais clara da interdependência dos direitos humanos e da necessidade de cooperação jurídica entre Estados e organismos internacionais para a afirmação e consolidação de orientações jurídicas que respeitem as diferenças.

\section{CONCLUSÃO}

Ante a existência de processos históricos que visavam anular suas diferenças, inicialmente com a prática do extermínio e, posteriormente, por meio de políticas assimilacionistas, as pessoas com deficiência foram colocadas em posição de marginalização e se viram impedidas de alcançarem sua plena realização, haja vista que o não acolhimento da singularidade de seus modos de interação com o espaço sempre resultou na negação de fatores imprescindíveis para sua existência digna.

deficiência. ONU. The Invisibility of Disability. 2016. Disponível em: http://www.un.org/disabilities/documents/sdgs/infographic_statistics_2016.pdf. Acesso em 23 jul. 2019.

${ }^{74}$ CORTE IDH, Caso “Atala Riffo e Crianças Vs. Chile”. Sentença de 24 de fevereiro de 2012. Disponivel em: http://www.corteidh.or.cr/cf/jurisprudencia2/index.cfm?lang=es. Acesso em 23 jul. 2019. 
ISSN 1981-3694

(DOI): $10.5902 / 1981369435067$

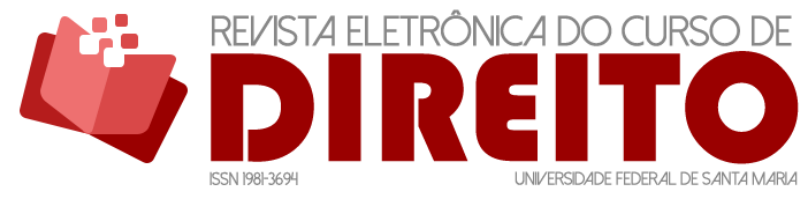

AFIRMAÇÃO E PROMOÇÃO DO DIREITO ÀS DIFERENÇAS DAS PESSOAS COM DEFICIÊNCIA E AS CONTRIBUICCÕES DO SISTEMA INTERAMERICANO DE DIREITOS HUMANOS

Pedro Pulzatto Peruzzo LUCAS SILVA LOPES

Já se vislumbrava o perigo da igualdade formal sem qualquer instrumento que viesse a acompanhar e garantir o enraizamento dos discursos que versam sobre os direitos humanos nos ordenamentos jurídicos internos. Neste sentido, os sistemas regionais e universal de proteção de direitos humanos têm se apresentado como instrumentos facilitadores dessas tarefas, na medida em que o acesso ao espaço público transnacional tem permitido a afirmação da visão acerca dos direitos humanos que entende o universal como um ponto de chegada e não de partida.

0 estabelecimento de um sujeito de direito universal que não suporta qualquer diferença substancial fortalecido por um modelo jurídico que reforça um modo de produção formal-individualista sempre constituiu empecilho para que grupos minoritários vislumbrassem qualquer possibilidade da superação do preconceito que marca suas existências ainda hoje. Todavia, o incessante processo de luta das pessoas com deficiência acabou por permitir que suas demandas fossem incorporadas a pautas internacionais de direitos humanos e fortalecidas por organismos que têm como objetivo proteger e promover a dignidade humana a partir de agendas globais que respeitam as diferenças, além de influenciar as instâncias jurídicas e administrativas dos Estados nacionais que, muitas vezes, acabam figurando como fatores que dificultam o reconhecimento e o exercício de direitos por grupos social e culturalmente diferenciados. A luta segue no sentido de afirmar a unidade das lutas de todos os grupos minoritários, considerando que, apesar das diferenças, a origem de grande parte das agressões é comum.

Nessa linha, o Sistema Interamericano de Direitos Humanos tem demonstrado êxito ao incluir nas pautas das pessoas com deficiência um esforço de afirmar a necessidade de compreender que as dificuldades decorrem de um modelo social de convivência e não das peculiaridades de cada grupo, de modo que a deficiência deixou de ser mero infortúnio pessoal e passou a ter como causa a estrutura social que é incapaz de respeitar as diferenças.

\section{REFERÊNCIAS}

ABADE, Denise Neves. Direitos fundamentais na cooperação jurídica internacional. - São Paulo: Saraiva, 2013, p. 40

ABRAMOVICH, Víctor. Das violações em massa aos padrões estruturais: novos enfoques e clássicas tensões no sistema interamericano de direitos humanos. São Paulo: SUR - Revista Internacional de Direitos Humanos, 2009. p. 10. Disponível em: http://sur.conectas.org/wpcontent/uploads/2017/11/sur11-port-debora-diniz-livia-barbosa-e-wederson-rufino-dossantos.pdf. Acesso em: 23 jul. 2019.

ARBEX, Daniela. Holocausto brasileiro. São Paulo: Geração Editorial, 2013. p. 25-26. 
BARALDI, C. B. F. PERUZZO, P. P. Democracia e Direitos Humanos: a participação social das minorias. Santa Maria, Revista Eletrônica do Curso de Direito da UFSM, 2015. p. 360.

Disponível em: https://periodicos.ufsm.br/revistadireito/article/view/19769/pdf. Acesso em: 23 jul. 2019.

BERNARDES, M. N. Sistema Interamericano de Direitos Humanos como Esfera Pública Transnacional: Aspectos Jurídicos e Políticos da Implementação de Decisões Internacionais. SUR -Revista Internacional de Direitos Humanos. vol. 11., n. 15, 2011. p. 139. Disponível em: https: / / sur.conectas.org/sistema-interamericano-de-direitos-humanos-como-esfera-publicatransnacional/. Acesso em: 23 jul. 2019.

BRASIL. Constituição Federal. Diário Oficial da República Federativa do Brasil, Brasília, 5 out. 1988. Disponível em:

http://www.planalto.gov.br/ccivil_03/constituicao/constituicaocompilado.htm. Acesso em: 23 jul. 2019.

BRASIL. Decreto $n^{\circ} 1.973$ de 01 de agosto de 1996. Promulga a Convenção Interamericana para Prevenir, Punir e Erradicar a Violência contra a Mulher, concluída em Belém do Pará, em 9 de junho de 1994. Diário Oficial da União, Brasília, 02 out. 1996. Disponível em: http://www.planalto.gov.br/ccivil_03/decreto/1996/d1973.htm. Acesso em: 24 jul. 2019.

BRASIL. Decreto $n^{\circ} 3.956$ de 08 de outubro de 2001. Promulga a Convenção Interamericana para a Eliminação de Todas as Formas de Discriminação contra as Pessoas Portadoras de Deficiência. Diário Oficial da União, Brasília, 09 out. 2001. Disponível em: http://www.planalto.gov.br/ccivil_03/decreto/2001/d3956.htm. Acesso em: 24 jul. 2019.

BRASIL. Decreto $n^{\circ} 10.741$ de 01 de outubro de 2003. Dispõe sobre o Estatuto do Idoso e dá outras providências. Diário Oficial da União, Brasília, 03 out. 2003. Disponível em: http://www.planalto.gov.br/ccivil_03/LEIS/2003/L10.741.htm. Acesso em: 24 jul. 2019.

BRASIL. Decreto $n^{\circ} 11.340$ de 07 de agosto de 2006. Cria mecanismos para coibir a violência doméstica e familiar contra a mulher, nos termos do § 80 do art. 226 da Constituição Federal, da Convenção sobre a Eliminação de Todas as Formas de Discriminação contra as Mulheres e da Convenção Interamericana para Prevenir, Punir e Erradicar a Violência contra a Mulher; dispõe sobre a criação dos Juizados de Violência Doméstica e Familiar contra a Mulher; altera o Código de Processo Penal, o Código Penal e a Lei de Execução Penal; e dá outras providências. Diário Oficial da União, Brasília, 08 ago. 2006. Disponível em: http://www.planalto.gov.br/ccivil_03/_ato2004-2006/2006/lei//11340.htm. Acesso em: 24 jul. 2018.

BRASIL. Decreto $n^{\circ} 4.377$ de 13 de setembro de 2002. Promulga a Convenção sobre a Eliminação de Todas as Formas de Discriminação contra a Mulher, de 1979, e revoga o Decreto no 89.460, de 20 de março de 1984. Diário Oficial da União, Brasília, 16 set. 2002. Disponível em: http://www.planalto.gov.br/ccivil_03/decreto/2002/d4377.htm. Acesso em: 24 jul. 2019.

BRASIL. Decreto $n^{\circ} 5.051$ de 19 de abril de 2004. Promulga a Convenção no 169 da Organização Internacional do Trabalho - OIT sobre Povos Indígenas e Tribais. Diário Oficial da União, Brasília, 
20 abr. 2004. Disponível em: http://www.planalto.gov.br/ccivil_03/_ato20042006/2004/decreto/d5051.htm. Acesso em: 24 jul. 2019.

BRASIL. Decreto $n^{\circ} 6.040$ de 07 de fevereiro de 2007. Institui a Política Nacional de Desenvolvimento Sustentável dos Povos e Comunidades Tradicionais. Diário Oficial da União, Brasília, 08 fev. 2007. Disponível em: http://www.planalto.gov.br/ccivil_03/_ato20042006/2006/lei/l11340.htm.

Acesso em: 24 jul. 2019.

BRASIL. Decreto $n^{\circ}$ 6.177 de 01 de agosto de 2007. Promulga a Convenção sobre a Proteção e Promoção da Diversidade das Expressões Culturais, assinada em Paris, em 20 de outubro de 2005. Diário Oficial da União, Brasília, 02 ago. 2007. Disponível em: http://www.planalto.gov.br/ccivil_03/_ato2007-2010/2007/decreto/d6177.htm. Acesso em: 24 jul. 2019.

BRASIL. Decreto No 6.949 de 25 de agosto de 2009. Promulga a Convenção Internacional sobre os Direitos das Pessoas com Deficiência e seu Protocolo Facultativo, assinados em Nova York, em 30 de março de 2007. Diário Oficial da União, Brasília, DF, 26 ago. 2009. Disponível em: http://www.planalto.gov.br/ccivil_03/_ato2007-2010/2009/decreto/d6949.htm. Acesso em: 23 jul. 2019.

BRASIL. Decreto $n^{\circ} 7.716$ de 05 de janeiro de 1989. Define os crimes resultantes de preconceito de raça ou de cor. Diário Oficial da União, Brasília, 06 jan. 1989. Disponível em:

http://www.planalto.gov.br/ccivil_03/decreto/1996/d1973.htm. Acesso em: 23 jul. 2019.

BRASIL. Decreto $n^{\circ} 8.727$ de 28 de abril de 2016. Dispõe sobre o uso do nome social e o reconhecimento da identidade de gênero de pessoas travestis e transexuais no âmbito da administração pública federal direta, autárquica e fundacional. Diário Oficial da União, Brasília, 29 abr. 2016. Disponível em: http://www.planalto.gov.br/ccivil_03/_ato2015-

2018/2016/decreto/d8727.htm. Acesso em: 23 jul. 2019.

BRASIL. Decreto $n^{\circ} 9.522$ de 08 de outubro de 2018. Promulga o Tratado de Marraqueche para Facilitar o Acesso a Obras Publicadas às Pessoas Cegas, com Deficiência Visual ou com Outras Dificuldades para Ter Acesso ao Texto Impresso, firmado em Marraqueche, em 27 de junho de 2013. Diário Oficial da União, Brasília, 08 out. 2018. Disponível em: http://www.planalto.gov.br/ccivil_03/_Ato2015-2018/2018/Decreto/D9522.htm. Acesso em: 23 jul. 2019.

BRASIL. Decreto n 19.841 de 22 de outubro de 1945. Promulga a Carta das Nações Unidas, da qual faz parte integrante o anexo Estatuto da Corte Internacional de Justiça, assinada em São Francisco, a 26 de junho de 1945, por ocasião da Conferência de Organização Internacional das Nações Unidas. Coleção de Leis do Brasil de 1945, Rio de Janeiro, 22 out. 1945. Disponível em: http://www.planalto.gov.br/ccivil_03/decreto/1930-1949/D19841.htm. Acesso em: 24 jul. 2019.

BRASIL. Decreto $n^{\circ} 65.810$ de 08 de dezembro de 1969. Promulga a Convenção Internacional sobre a Eliminação de todas as Formas de Discriminação Racial. Diário Oficial da União, Brasília, 10 dez. 1969. Disponível em: http://www2.camara.leg.br/legin/fed/decret/1960-1969/decreto65810-8-dezembro-1969-407323-publicacaooriginal-1-pe.html. Acesso em: 23 jul. 2019. 
BRASIL. Decreto $n^{\circ} 678$ de 06 de novembro de 1992. Promulga a Convenção Americana sobre Direitos Humanos (Pacto de São José da Costa Rica), de 22 de novembro de 1969. Diário Oficial da União, Brasília, 09 nov. 1992. Disponível em: http://www.planalto.gov.br/ccivil_03/Decreto/D0678.htm. Acesso em: 23 jul. 2019.

BRASIL. Lei $n^{\circ}$ 6.001/73 de 19 de dezembro de 1973. Dispõe sobre o Estatuto do Índio. Diário Oficial da União, Brasília, 21. dez. 1973. Disponível em:

http://www.planalto.gov.br/ccivil_03/Leis/L6001.htm. Acesso em 24. jul. 2019.

BRASIL. Lei $n^{\circ}$ 13.146, de 6 de julho de 2015. Institui a Lei Brasileira de Inclusão da Pessoa com Deficiência (Estatuto da Pessoa com Deficiência). Diário Oficial da União, Brasília, 7 jul. 2015.

BRASIL. Lei $n^{\circ} 13.257$ de 08 de março de 2016. Dispõe sobre as políticas públicas para a primeira infância e altera a Lei no 8.069, de 13 de julho de 1990 (Estatuto da Criança e do Adolescente), o Decreto-Lei no 3.689, de 3 de outubro de 1941 (Código de Processo Penal), a Consolidação das Leis do Trabalho (CLT), aprovada pelo Decreto-Lei no 5.452, de 10 de maio de 1943, a Lei no 11.770, de 9 de setembro de 2008, e a Lei no 12.662, de 5 de junho de 2012. Diário Oficial da União, Brasília, 29 abr. 2016. Disponível em: http://www.planalto.gov.br/CCIVil_03/_Ato20152018/2016/Lei/L13257.htm. Acesso em: 24 jul. 2019.

BRASIL. Secretaria de Direitos Humanos da Presidência da República, Cartilha do Censo 2010: pessoas com deficiência [online]. Brasília, 2012. p. 15-18.)Disponível em:

https://biblioteca.ibge.gov.br/visualizacao/periodicos/94/cd_2010_religiao_deficiencia.pdf. Acesso em 23 jul. 2019.

CARTILHA DO CENSO 2010 - Pessoas com Deficiência. Secretaria de Direitos Humanos da Presidência da República (SDH/PR); Secretaria Nacional de Promoção dos Direitos da Pessoa com Deficiência (SNPD); Brasília: SDH-PR/SNPD, 2012. Disponível em:

https://biblioteca.ibge.gov.br/visualizacao/periodicos/94/cd_2010_religiao_deficiencia.pdf. Acesso em: 23 jul. 2019.

CHACON DE ALBUQUERQUE, Roberto., A Lei de Prevenção de Doenças Hereditárias e o programa de eutanásia durante a Segunda Guerra Mundial. CEJ - Revista Jurídica dos Centros de Estudos Judiciários, v. 12, no 40, 2008. p. 43-51. Disponível em: http://www.jf.jus.br/ojs2/index.php/revcej/article/viewArticle/961. Acesso em 23 jul. 2019.

COPETTI NETO, ALFREDO; SILVA, ALEXANDRE BARBOSA DA. A inconstitucionalidade da proposta de retorno à incapacidade da pessoa com deficiência (Pls 757/2015) frente à Convenção de Nova Iorque. REVISTA ELETRÔNICA DO CURSO DE DIREITO DA UFSM, Santa Maria,RS v. 13, p. 980, 2018. ISSN 1981-3694. DOI: http://dx.doi.org/10.5902/1981369432004. Disponível em: https://periodicos.ufsm.br/revistadireito/article/view/32004. Acesso em 22 Jul. 2019.

CORTE IDH, Caso “Atala Riffo e Crianças Vs. Chile”. Sentença de 24 de fevereiro de 2012. Disponivel em: http://www.corteidh.or.cr/cf/jurisprudencia2/index.cfm?lang=es. Acesso em 23 jul. 2019. 
CORTE IDH, Caso “Furlan e familiares Vs. Argentina”. Sentença de 31 de agosto de 2012, parágrafo 114. Disponível em:

http://www.corteidh.or.cr/docs/casos/articulos/seriec_246_esp.pdf. Acesso em 23 jul. 2019.

CORTE IDH, Caso Ximenes Lopes Vs Brasil. Mérito, Reparações e Custas. Sentença de 4 de julho de 2006, parágrafo 123. Serie $\mathrm{N}^{\circ} 149$. Disponível em:

http://www.corteidh.or.cr/docs/casos/articulos/seriec_149_por.pdf. Acesso em 23 jul. 2019.

CORTE IDH. Caso “Povo Indígena Kichwa de Sarayakuvs Equador”. Sentença de 27 de julho de 2012, parágrafo 161. Disponível em:

http://corteidh.or.cr/docs/casos/articulos/seriec_245_esp.pdf. Acesso em 23 jul. 2019.

DINIZ, Debora. O que é deficiência? Brasília: Brasiliense, 2007. p. 14.

FLORES, Joaquin Herrera. Direitos humanos, interculturalidade e racionalidade de resistência. Sequiência - Estudos Jurídicos e Políticos. vol. 23, no 44. 2002. p. 9. Acesso em:

https://periodicos.ufsc.br/index.php/sequencia/article/view/15330/13921. Acesso em: 23. jul. 2019.

GOFFMAN, Erving. Estigma: notas sobre a manipulação da identidade deteriorada. Rio de Janeiro: LTC, 1988.

GOULD, Stepen Jay. A falsa medida do homem. São Paulo: Martins Fontes, 1999. p. 26.

HONNETH, Axel. Luta por reconhecimento: a gramática moral dos conflitos sociais. Tradução de Luiz Repa. São Paulo: 34, 2003. p. 18.

LACLAU, E. New social movements and the plurality of the social; In SLATER, D. (org) New social movements and the State in Latin America. Amsterdam: Centrum VoorStudieenDocumentatie Vans Latijns Amerika [CEDLA], 1985, pp. 27-42.

MELLO, Anahi Guedes de. Deficiência, incapacidade e vulnerabilidade: do capacitismo ou a preeminência capacitista e biomédica do Comitê de Ética em Pesquisa da UFSC. Ciência\&Saúde Coletiva [online]. v. 21, n. 10. 2016. p. 3265-3276. Disponível em:

http://www.scielo.br/pdf/csc/v21n10/1413-8123-csc-21-10-3265.pdf. Acesso em: 23 jul. 2019.

MELO, Mario. Últimos avanços na justiciabilidade dos direitos indígenas no Sistema Interamericano de Direitos Humanos. São Paulo: SUR - Revista Internacional dos Direitos Humanos, 2006. p. 26. Disponível em: https://sur.conectas.org/ultimos-avancos-najusticiabilidade-dos-direitos-indigenas-no-sistema-interamericano-de-direitos-humanos/. Acesso em: 23 jul. 2019.

OEA. CONVENCIÓN INTERAMERICANA CONTRA TODA FORMA DE DISCRIMINACIÓN E INTOLERANCIA. Guatemala, 05. jun. 2013.

ONU, Comitê sobre os Direitos das Pessoas com Deficiência. Comunicação $n^{\circ} 3 / 2011$, Caso H. M. Vs. Suécia. CRPD/C/7/D/3/2011, 19 de abril de 2012. 
ONU. The Invisibility of Disability. 2016. Disponível em:

http://www.un.org/disabilities/documents/sdgs/infographic_statistics_2016.pdf. Acesso em: 23 jul. 2019.

PERUZZO, P. P. Direito à consulta prévia aos povos indígenas no Brasil. Direito \&Praxis. vol.8. n. 4. 2017. Disponível em: https://www.epublicacoes.uerj.br/index.php/revistaceaju/article/view/24631. Acesso em: 23 jul. 2019.

PIMENTEL, MARIANA COUTO; PIMENTEL, Susana Couto. Acessibilidade como um direito fundamental: uma análise à luz das leis federais brasileiras. Revista Eletrônica do Curso de Direito da UFSM, Santa Maria, RS, v. 13, 2018, p. 93.

DOI: http://dx.doi.org/10.5902/1981369427961. Disponível em:

https://periodicos.ufsm.br/revistadireito/article/view/27961. Acesso em 22 Jul.2019.

RAMOS, André de Carvalho. Curso de direitos humanos. 1. ed. São Paulo: Saraiva, 2014. p. 137.

RAMOS, André de Carvalho. O novo Direito Internacional Privado e o conflito de fontes na cooperação jurídica internacional. R. Fac. Dir. Univ. São Paulo, v. 108, p. 621 - 647 jan./dez. 2013

ROUANET, S. P. Mal-estar na modernidade: ensaios. São Paulo: Companhia das Letras, 1993. p. 274.

SANTOS, Boaventura de Sousa. Por uma concepção multicultural de direitos humanos. Revista Crítica de Ciências Sociais. $N^{\circ} 48,1997$. p. 18.

SILVA, Otto Marques da. A epopeia ignorada: (a pessoa deficiente na historia do mundo de ontem e de hoje). São Paulo: CEDAS,1987.

SIMÕES, André et al (Org.). Panorama Nacional e Internacional na Produção de Indicadores Sociais: Grupos populacionais específicos e uso do tempo. Rio de Janeiro: IBGE, 2018. Disponível em: https://biblioteca.ibge.gov.br/visualizacao/livros/liv101562.pdf. Acesso em: 22 jul. 2019

SOUSA, Rosinaldo S. Direitos Humanos através da História recente em uma Perspectiva Antropológica.In Roberto Kant de Lima; Regina Novais. (Org.). Antropologia e Direitos Humanos. Niterói: EdUFF, v. 30, 2002, p. 47-80.

TRINDADE, Antônio Augusto Cançado. A proteção internacional dos direitos humanos e o Brasil. Brasília: Universidade de Brasília.

WERNECK, Claudia. (2003), Você é gente? Rio de Janeiro: WVA, 2003. p. 52.

WOLKMER, Antonio Carlos; LEITE, J. R. M. (Org.). Os 'novos' direitos no Brasil - Natureza e Perspectivas - Uma visão básica das novas conflituosidades jurídicas. 2. ed. São Paulo: Saraiva, 2012. v. 1. p. 32-35.

YEPES, Rodrigo Uprimny; DUQUE, Luz María Sánchez. Convención Americana sobre Derechos Humanos - Comentario. Berlín: Konrad AdenauerStiftung, 2014. p. 587-588. 


\section{COMO FAZER REFERÊNCIA AO ARTIGO (ABNT):}

PERUZZO, Pedro Pulzatto; LOPES, Lucas Silva. Afirmação e promoção do direito às diferenças das pessoas com deficiência e as contribuições do sistema interamericano de direitos humanos. Revista Eletrônica do Curso de Direito da UFSM, Santa Maria, RS, v. 14, n. 3, e35067, set./dez. 2019. ISSN 1981-3694. DOI: http://dx.doi.org/10.5902/1981369435067. Disponível em: https://periodicos.ufsm.br/revistadireito/article/view/35067 Acesso em: dia mês. ano.

Direitos autorais 2019 Revista Eletrônica do Curso de Direito da UFSM

Editores responsáveis: Rafael Santos de Oliveira e Angela Araujo da Silveira Espindola

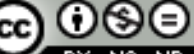

Esta obra está licenciada com uma Licença Creative Commons Atribuição-NãoComercial-SemDerivações 4.0 Internacional.

\section{SOBRE OS AUTORES}

\section{Pedro Pulzatto Peruzzo}

Professor Titular Categoria A1 da PUC-Campinas. Membro do corpo docente permanente do Programa de Pós-Graduação stricto sensu em Direito (PPGD), vinculado à linha de pesquisa "Cooperação Internacional e Direitos Humanos". Membro do grupo de pesquisa "Direito num mundo globalizado" (CNPq/PUC Campinas). Na graduação, professor das disciplinas Direitos Humanos, Direito Penal Internacional e Metodologia Jurídica. Doutor (2015) e mestre (2011) em Direito pela Universidade de São Paulo-USP. Advogado graduado pela PUC-Campinas em 2007, consultor geral da Comissão de Direitos Humanos da Ordem dos Advogados do Brasil - seccional São Paulo (2019). Realizou, durante o doutorado, estágio em pesquisa na Faculdade de Educação da Universidade de Alcalá - Espanha - entre janeiro e fevereiro de 2015, pesquisando experiências de educação inclusiva de imigrantes e ciganos. Tem interesse em pesquisa empírica e experiência acadêmica na área de Direitos Humanos, com ênfase em Antropologia do Direito, atuando principalmente nos seguintes temas: direitos humanos, direito internacional, pessoa com deficiência, hanseníase, povos indígenas, minorias, democracia participativa, diálogo intercultural e desenvolvimento social.

\section{LUCAS SILVA LOPES}

Discente pesquisador no programa de iniciação científica no período de 2016-2017 pela Pontifícia Universidade Católica de Campinas, bacharelando em Direito pela mesma universidade, Auxiliar Jurídico na empresa BYD. 